\title{
Mismatches in the urbanization process of informal settlements in Morro da Cruz - Florianopolis, SC
}

\author{
Desencontros no processo de urbanização de assentamentos precários no \\ Morro da Cruz - Florianópolis, SC
}

Sonia Rohling Soares[a] (D), Sérgio Torres Moraes ${ }^{[b]}$ (D)

[a] Universidade Federal de Santa Catarina (UFSC/BR), Departamento de Arquitetura e Urbanismo, Programa de Pós-Graduação em Arquitetura e Urbanismo (Pós-ARQ), Centro Tecnológico, Florianópolis, SC, Brasil

[b] Universidade Federal de Santa Catarina (UFSC), Curso de Arquitetura e Urbanismo, Departamento de Arquitetura e Urbanismo, Centro Tecnológico, Florianópolis, SC, Brasil

How to cite: Soares, S. R., \& Moraes, S. T. (2019). Mismatches in the urbanization process of informal settlements in Morro da Cruz - Florianopolis, SC. urbe. Revista Brasileira de Gestão Urbana, 11, e20170199. https://doi.org/10.1590/21753369.011.e20170199

\begin{abstract}
Brazilian political-administrative structures often arise on institutional and legal mazes, reducing the effectiveness to solve the unsatisfactory living conditions in poor communities. Unraveling conflicts and finding alternative can contribute to better life quality and improved structures. This article discusses the lack of coherence among technical diagnoses, community demands, and actions of public administration in urban areas exposed to landslide risk, and studies the case of informal settlements of Morro da Cruz, in Florianópolis, southern Brazil. The susceptibility to landslides and the poor living conditions of about $40 \%$ of the population living there, led these communities to receive investments from the Growth Acceleration Program (PAC) of Brazil's Federal Government which main interventions (2009-2016) should be the construction of social housing and land regularization for the inhabitants since the data showed in 2008 a deficit of 438 houses and had $80 \%$ of properties without due documentation. An evaluation in 2016 showed those interventions in Morro da Cruz improved living conditions, however, they did not complete land regularization, eliminate the housing deficit nor the susceptibility. In conclusion, we point out the main gaps in the process and the possible support for an improvement of the structures for such interventions in the Brazilian context.
\end{abstract}

Keywords: Urbanization. Public policies. Informal settlements. Landslide.

\section{Resumo}

As estruturas político-administrativas brasileiras frequentemente se erguem em labirintos institucionais e legais, reduzindo a solução efetiva das condições de vida insatisfatórias em comunidades pobres. Desvendar conflitos e encontrar alternativas podem contribuir para a melhoria da qualidade de vida e das estruturas. Este artigo discute a falta de coerência entre diagnósticos técnicos, demandas comunitárias e ações público-administrativas em áreas urbanas expostas ao risco de escorregamentos, estudando o caso 
de assentamentos informais do Morro da Cruz, Florianópolis. A suscetibilidade a deslizamentos de terra e as demais condições precárias de vida de cerca de 40\% da população residente os levaram a receber investimentos do Programa de Aceleração do Crescimento (PAC) do governo federal brasileiro, cujas principais intervenções (2009-2016) deveriam ter sido construção de habitação social e regularização fundiária, uma vez que os dados mostraram em 2008 um déficit de 438 casas e 80\% das propriedades sem a devida documentação. Uma avaliação, em 2016, mostrou que as intervenções no Morro da Cruz melhoraram as condições de vida mas não concluíram a regularização fundiária, não eliminaram o déficit habitacional nem a suscetibilidade. Para concluir, apontamos algumas lacunas do processo e o possível suporte para a melhoria das estruturas correspondentes a tais intervenções no contexto brasileiro.

Palavras-chave: Urbanização. Políticas públicas. Assentamentos informais. Deslizamento.

\section{Introduction}

The dynamics of urban space production and the organization of physical structures are strongly related to environmental problems (Gorski, 2010). Among many actors of this production, the State stands out as the principal mediator between social and environmental justice. Thus, to understand its' decisions it is necessary to discuss the results of actions that might affect the life quality and the of the environment, mainly in poor communities.

For Undp-World Bank (1999) the urbanization of informal settlements consists of promoting physical, social, economic, organizational and environmental, promoted locally and in partnership with community groups, local government, NGOs, private sector. They should include: provision or improvement of infrastructure; environmental recovery; incentives for community management and maintenance; construction or renovation of community facilities; land regularization; housing improvement; relocation/compensation for the small number of residents dislocated by the improvements); access to social programs (education, health, safety); access to income generation programs; construction of 'social capital' and institutional structure to sustain improvement. Larger projects are coupled with institutional reforms to improve government performance. Investments in housing and urban development are directed toward integrated sanitation, environmental restoration, and informal settlement's urbanization programs. The development of integrated policies to improve settlements and multisectoral actions is worthy (Denaldi, 2003, p. 34-35).

In this sense, this paper will investigate and discuss the options of the Federal Government of Brazil and Municipal government of the city of Florianópolis regarding the urbanization of an informal settlement at an environmentally sensitive area. This discussion tries to find out to what extent the implemented work's directives were effective to promote better life quality, decrease risks related to landslide and respond to housing deficit and it also brings us an expectation of improvement of the mechanisms aimed at the protection and development of informal urbanization on slopes (Figure 1).

The rapid urbanization of Brazilian cities and negligent public policies related to the control of urban development since the early 1970's has created high levels of urban inequalities and many social and environmental problems. From the 1970's the Brazilian Federal Government triggered several programs aimed at minimizing the housing crisis as the Housing Policy - BNH (Brazil National Housing Bank, 19641986); Habitar Brazil IDB (Bonduki, 1998). After the year 2000, other programs as the Social Rental Program - PAR (Brasil, 2001a); New House Program (2003-2009) and the PMCMV - My Home My Life Program (2009-2018) composed the government policies' arsenal to cope with the housing problem. Brazil had 11.42 million people living in informal settlements in 2010 corresponding to $6 \%$ of the country's (IBGE, 2011). The comparison with the previous Census may give us the extent of the informal housing increase. In 1991, 4.48 million people (3.1\% of the population) lived in informal settlements and 6.53 million $(3.9 \%)$ were in this condition in the 2000 Census.

In 2008, the Federal Government launched another important development policy - the Growth Acceleration Program (PAC). This program aims, among several objectives, to provide a budget for 
Municipalities and States to build infrastructures attempting to minimize the effects of the irregular urban expansion problem and to provide social housing. The PAC was welcome in spite of to raise several questions on its efficiency, since it focus attention more on urban infrastructure rather than in housing deficit, ignoring the increase of the number of informal settlements ${ }^{1}$ in the country since then.

In Florianópolis, it was not different. Here, Housing and Enviro-Sanitation Secretary (SMHSA) was responsible for PAC's funds' management. To accomplish the task this Municipal Secretary developed between 2007 and 2008 a diagnosis of the housing and infrastructure conditions of city's informal settlements and choose the most precarious neighborhood (Morro da Cruz neighborhood) where PAC funds should be used.

Despite the diagnosis showed a big housing deficit (including houses in landslide risk areas), the SMHSA priorities to improve landslides' threated communities did not follow the findings in that report nor many directives from the city's Master Plan. Instead they priories draining systems and walls containment works.

Thus, to approach the informal settlement's urbanization and examine the process of urbanization in the Morro da Cruz we start briefly presenting vulnerable and informal settlements' urbanization policies around the globe. Thereafter, to discuss the lack of coherence among technical diagnosis, community demands, and actions done by public administration in urban areas exposed to the risk of landslides, we present the urban and environmental legislation context, policies and programs to regulate, induce or inhibit urban development, providing some criteria of social inclusion and environmental sustainability in Brazil.

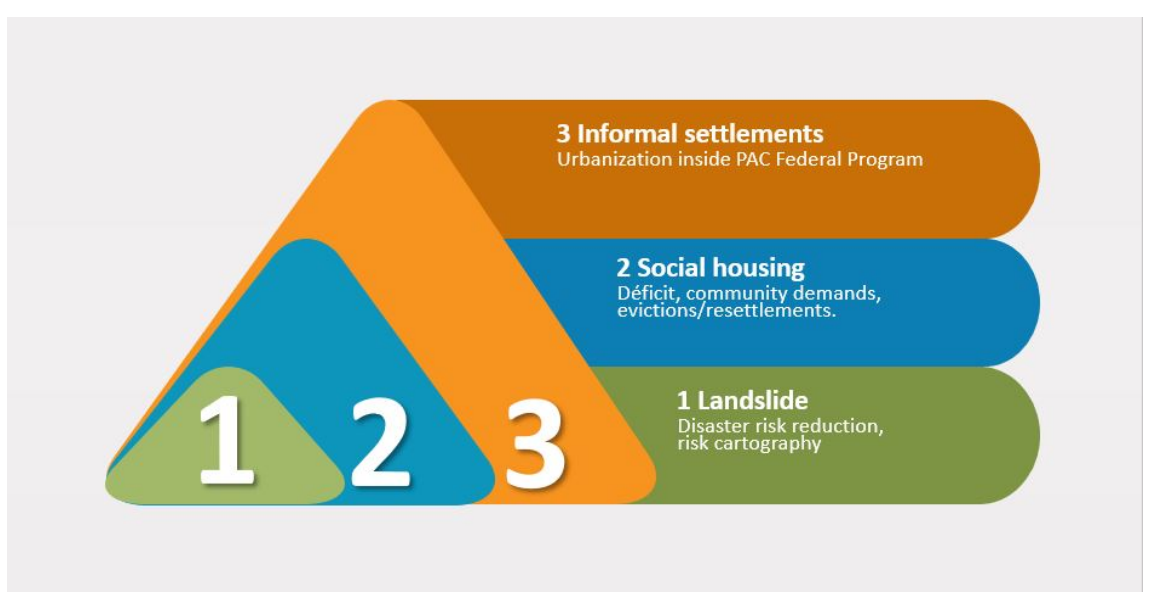

Figure 1 - Diagram with keywords related issues. Source: The authors.

\section{Vulnerable and informal settlements urbanization}

Many settlements across the globe face a constant threat of landslides, the result of a formidable combination of geological, climatic and developmental factors. Within a global perspective, the United Nations' by their UNISDR (United Nations Office for Disaster Risk Reduction, United Nations, 2008) developed a framework to help countries to reduce the impact of natural disasters, including landslides. The Sendai Framework (successor of the Hyogo Framework for Action -HFA, 2005-2015), a 15-year, voluntary, non-binding agreement, recognizes that the State has the primary role to reduce disaster risk, but that responsibility should be shared with other stakeholders including local government, the private sector and other stakeholders (United Nations, 2015).

1The term "informal settlement" is based on the definition of "subnormal agglomerates": each group of more than 50 substandard houses, characterized by lack of essential public infrastructure and services in a public or private area, dense and randomly distributed (IBGE, 2011). 
Among the Sendai Chart priorities', there is the statement that public and private investment in disaster risk prevention and reduction should be done through structural and non-structural measures considered essential to enhance the economic, social, health and cultural resilience of persons, communities, countries and their assets, as well as the environment.

Despite this directive, critics worldwide warn that many governments tend to invest much more in disaster mitigation and relief than in reducing exposure to hazards. For instance, the Chinese government approved in June 2014 a \$483-million project to improve monitoring in the Zhangmu region. Engineers will install sensors to determine pore-water pressure and implement measures to stabilize slopes, drain rainwater and block debris flow (Qiu, 2014). Also, in Brazil, the government actions aimed at the natural disaster's management are more directed to structural measures rather than non-structural measures as show Avila \& Mattedi (2017) studying the case of Blumenau in Santa Catarina State. There, the government actions to natural disasters relief were given primarily through hydraulic works (dams and river "improvement"), disregarding rules of land use, deforestation, forms of occupation as essential factors for the recrudescence of disasters (Avila \& Mattedi, 2017).

The occupation of non-proper areas to urbanization in Brazil is a direct consequence of decades of neglect of the State on housing policies and on environmental and urban planning control. As a result, informality, precariousness, and vulnerability come to be the predominant urban standard of the territories occupied by low-income strata (Moraes, 2018). In this context, comes up a real estate market logic that favors the middle and high-income classes with areas with better infrastructure, relegating to the low-income population areas in the peripheries with less favorable geological conditions or with environmental restrictions (cf. Maricato, 2001).

Thus, the public actions aimed at the urbanization of informal settlements and/or in areas of landslide risk should have prioritized security, decent housing and life quality. Any action or proposal in such areas should have guaranteed the sustainability and resilience as well right to the city for every dweller of these communities.

Despite several legal advances, the Brazilian reality public administration's actions usually do not run like they should have to. In Rio de Janeiro State, for instance, a strong rainfall period ${ }^{2}$ in January 2011 caused extreme events of landslides ${ }^{3}$ with human and economic losses. Campanaro et al. (2014) estimated that floods and landslides in Rio had approximately a total cost of $\mathrm{R} \$ 5,32$ billion, part of it (R\$ 2,27 billion) due to the housing sector.

\section{Methodological approaches}

For the discussion, we have chosen the case study of Morro da Cruz in Florianópolis. This choice was very convenient since this informal occupied hill was put by 2008 at the center of the public investments, which aimed at decreasing landslide risks in Florianópolis.

Also, a study developed by the SMHSA-CEPED-UFSC in 2006 and 2007 was very useful for our study, since it 1) collects and organizes data of the socioeconomic and environmental profile of families of risk areas in Morro da Cruz informal settlements; and 2) presents the criteria of living conditions in Morro da Cruz - Florianopolis/SC before PAC interventions. We used this data to evidence the poor living

\footnotetext{
${ }^{2}$ The unusually heavy rains were attributed by some meteorologists to La Niña, but human activity likely exacerbated the scale of the disaster. Rapid population growth in the area has led Brazilians to build favelas (self-built settlements) on the steep slopes above Teresópolis. Those structures have been built on previously forested land, so the reduced tree cover has diminished the ability of the soil to hold water and the hills to hold onto the soil. Many of the houses lost, according to reports, were built on slopes of 45 degrees or more or in the buffer zones around rivers and streams. The Brazilian Forest Code officially forbids building in such areas (Nasa, 2011).

${ }^{3}$ This event reached mainly the cities at the mountainous suburbs around Rio de Janeiro City, as the cities of Nova Friburgo, Teresópolis and Petrópolis. It caused more than 1,500 deaths and severe damage to the urban and rural infrastructures (Coelho Netto, 2011, p. 1).
} 
conditions in Morro da Cruz before the urban improvements and social housing projects and to reassert the need for social housing.

We have observed the following issues: a) informal settlements, b) social housing and c) landslide. The informal settlements are understood from their urbanization inside PAC Federal Program, social housing according to the deficit, community demands, evictions/resettlements, and landslide by disaster risk reduction and risk cartography.

Therefore, we describe and analyze the case study of Morro da Cruz hill through four different documents: 1) CEPED-UFSC studies (Table 1); 2) the risk cartography developed by Rego Neto (1987); 3) the budget from PAC to Morro da Cruz from 2009 to 2016 and 4) Florianopolis Master Plan by 2014.

Table 1 - CEPED-UFSC STUDIES on housing and living conditions' variables

\begin{tabular}{cc}
\hline Housing and Living Conditions & VARIABLES \\
\hline Socioeconomic and environmental profile & $\begin{array}{c}\text { Dwellers by H.U; Rooms for HU; Density + than one Family } \\
\text { for HU; Density + 3 people for a room; Pauperized } \\
\text { housing; Poor living conditions }\end{array}$ \\
$\begin{array}{c}\text { Households in inadequate sanitary condition, } \\
\text { b) Informality in the access and use of electric }\end{array}$ \\
$\begin{array}{c}\text { Criteria of living conditions in Morro da Cruz before PAC } \\
\text { interventions }\end{array}$ & $\begin{array}{c}\text { engy/electricity, c) Without access to the water supply } \\
\text { system, d) Without sewerage collection, e) Without } \\
\text { waste collection, f) Without pavement, g) Without } \\
\text { access to public transportation (system), h) Difficult } \\
\text { mobility/ accessibility (\%). }\end{array}$ \\
\hline
\end{tabular}

Source: adapted by the authors from CEPED (UFSC, 2006 apud Florianópolis, 2007, p. 9-13).

At the same time, we proceeded new analysis regarding social housing. In order to verifying the effectiveness $^{4}$ of the social housing projects in Morro da Cruz (SMHSA actions) the data on the list of the communities' priorities established in the SMHSA reports (Florianópolis, 2007, 2008b) was compared to the data of resources investments on social housing built by PAC at the Morro da Cruz (2009-2016). In addition, we study the characterization and spatial location of social housing projects, what led us to identify urban restrictions at the edge of the urban and environmentally fragile areas of the slopes at the Morro da Cruz.

The methodological structure of this paper was set up on the keywords (informal settlements, social housing, and landslides) and their related issues, and on description of the case study through different aspects - the Ceped-UFSC studies, risk cartography studies, land use and social housing projects, and recent interventions made by the PMF to fulfill the urban infrastructure for landslide risk containment. The steps of analysis are supported by some "have to know" information as urban and environmental Federal and Municipal Legislation, the Florianópolis Master Plan, and PMF actions data. This structure is depicted below, showing how, what, and why that support information was considered, identified or verified (Table 2).

${ }^{4}$ The term "effectiveness" here is understood in governance measures efficiency, subsidiarity, and strategic vision and in security addresses conflict resolution, human security and environmental safety by the framework for developing indicators for the Urban Governance Index (Un-Habitat, 2004). 
Table 2 - Methodological Structure

\begin{tabular}{|c|c|c|c|c|}
\hline KEYWORDS & $\begin{array}{l}\text { Description of case } \\
\text { study through } \\
\text { different aspects }\end{array}$ & Steps of analysis & $\begin{array}{l}\text { "have to know" } \\
\text { support } \\
\text { information: }\end{array}$ & How?/what?why? \\
\hline Informal settlements: & & $\begin{array}{l}\text { Technical diagnosis } \\
\text { readings }\end{array}$ & \multirow[b]{2}{*}{ Cities Statute } & \multirow{2}{*}{$\begin{array}{l}\text { Evidences of poor } \\
\text { living conditions in } \\
\text { Morro da Cruz } \\
\text { before the urban } \\
\text { improvements and } \\
\text { social housing } \\
\text { deficit. }\end{array}$} \\
\hline $\begin{array}{l}\text { Urbanization matters } \\
\text { inside PAC }\end{array}$ & $\begin{array}{l}\text { 1) CEPED-UFSC } \\
\text { 2006-2007 studies; }\end{array}$ & $\begin{array}{l}\text { Florianópolis Master } \\
\text { Plan reading }\end{array}$ & & \\
\hline \multirow{3}{*}{$\begin{array}{l}\text { Social housing: Housing } \\
\text { deficit, community } \\
\text { demands, } \\
\text { evictions/resettlements. }\end{array}$} & \multirow{2}{*}{$\begin{array}{l}\text { 2) land use and } \\
\text { social housing; } \\
\text { 3)recent } \\
\text { interventions. }\end{array}$} & \multirow{2}{*}{$\begin{array}{c}\text { Community } \\
\text { demands } \\
\text { PMF Actions data } \\
\text { and Florianópolis } \\
\text { Master Plan }\end{array}$} & & \multirow{2}{*}{$\begin{array}{l}\text { Identify urban } \\
\text { restrictions at the } \\
\text { edge of urban } \\
\text { areas }\end{array}$} \\
\hline & & & ZEIS legislation & \\
\hline & \multirow{3}{*}{$\begin{array}{l}\text { 4) risk cartography } \\
\text { maps from Rego } \\
\text { Neto }\end{array}$} & \multirow{3}{*}{$\begin{array}{l}\text { Technical diagnosis } \\
\text { interpretation and } \\
\text { PMF Actions data }\end{array}$} & International and & \multirow{3}{*}{$\begin{array}{l}\text { Verify of the } \\
\text { effectiveness of the } \\
\text { social housing } \\
\text { projects and } \\
\text { landslide risk } \\
\text { reduction. }\end{array}$} \\
\hline \multirow{2}{*}{$\begin{array}{l}\text { Landslide: Disaster risk } \\
\text { reduction, risk } \\
\text { cartography }\end{array}$} & & & $\begin{array}{l}\text { Brazilian context } \\
\text { and examples }\end{array}$ & \\
\hline & & & $\begin{array}{l}\text { Environmental } \\
\text { legislation }\end{array}$ & \\
\hline
\end{tabular}

Source: The authors.

\section{Brazilian urban and environmental legislation context}

The Brazilian Federal government set up in the last years a legal backbone for a more sustainable urban and environmental development. From the 1980's, new environmental subjects are included since the first Federal Forestry code of 1965 . Those refer to the licensing process, conservation units and their proper uses.

From 1994 and 1997, the federal laws started to be reviewed to improve the procedures and criteria used to release environmental licensing. An important legal benchmark is the National Policy on Protection and Civil Defense Federal Law 12,608 (Brasil, 2012a). This policy consists in a specific legislation on risk reduction and supposedly "integrated with other policies of territorial planning (Figure 2), aiming to promote a sustainable development (Federal Law 12608, Brasil, 2012a) and ensure a rational connection to actions aimed to endow better life quality to informal settlements.

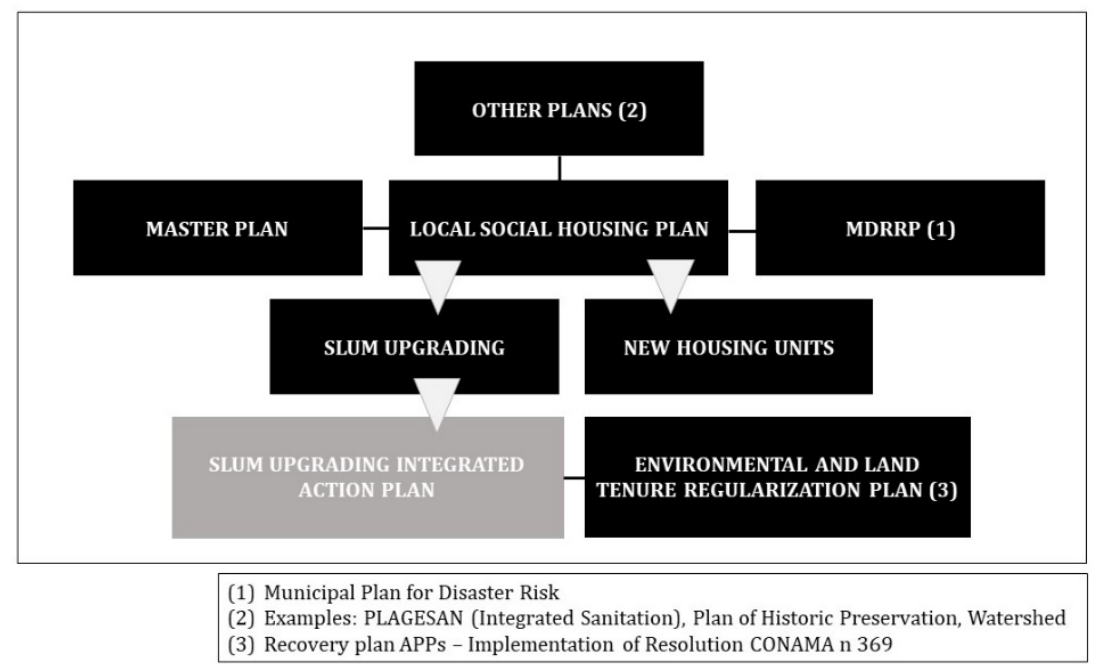

Figure 2 - Public Policies Interconnections. Source: Moretti et al. (2009), p. 60. 
The Federal Law 12,608 (Brasil, 2012a) also establishes that municipalities with areas susceptible to the occurrence of high impact landslides, sudden floods or related geological or hydrological processes, must prepare a "Geotechnical Chart of Suitability for Urbanization" (GCSU) and use it to set up their Master Plans. Originated to establish urban planning directives focused on the safety of land parceling, the GCSU aims at the prevention of natural disasters and to discipline the use and occupation of the urban land.

Even though current Brazilian Forestry Code - Federal Law 12,651 (Brasil, 2012b) promotes the protection and the sustainable use of the native greenery, it is not enough to avoid the urban expansion in risk areas caused by economic and social problems.

In 2001, the City Statute, Federal Law 10,257 (Brasil, 2001), brought up new possibilities for interventions. This Federal Law followed the principle of social function of property and it was aimed at promoting land reform in urban areas, changing the elitist nature of existing policies and programs. It provided a range of instruments to be used by public administrators, especially within the context of Municipal Master Plan to regulate, induce or inhibit urban development, providing some criteria of social inclusion and environmental sustainability to urban development (Fernandes, 2007). Among these urban management tools, the definition of the Special Social Interest Zones (ZEIS) represents a new milestone towards regulating social housing programs to allow social housing in better-urbanized areas, regulating land tenure and complementing urban infrastructural improvements inside informal settlements. The ZEIS is a category dedicated only to social housing.

Table 3 synthesizes the main Federal legislation, their establishment, and instruments that may help to natural disasters management and/or social housing.

Table 3 - Federal Legislation, establishment and instruments (1965-2012)

\begin{tabular}{cccc}
\hline Legislation & Law number & Year & Establishment and instruments \\
\hline $\begin{array}{c}\text { Forestry Code (Brasil, } \\
\text { 2012b) }\end{array}$ & 4771 & 1965 & $\begin{array}{c}\text { Licensing process and proper uses of } \\
\text { conservation units }\end{array}$ \\
$\begin{array}{c}\text { National Policy on } \\
\text { Protection and Civil } \\
\text { Defense }\end{array}$ (Brasil, \\
$\begin{array}{c}2012 \mathrm{a} \text { ) } \\
\begin{array}{c}\text { City Statute (Brasil, } \\
\text { 2001) }\end{array}\end{array}$ & 12651 & 2012 & $\begin{array}{c}\text { Promotes the protection and the sustainable } \\
\text { Use of natural greenery } \\
\text { Risk cartography }\end{array}$ \\
\hline
\end{tabular}

Source: Adapted from Brazilian Federal Legislation from 1965-2012.

Many Government actions as the Growth Acceleration Program (PAC) has been developing strategies to cope with housing problems. The PAC subprogram "My House, My Life" (PMCMV) was launched aiming to provide public housing provision for low-income people. The housing units from the program Minha Casa, Minha Vida - My House My Life (Brasil, 2009) are designated for low-income populations that are unable to access decent housing through conventional financing. The program rules ${ }^{6}$ facilitate financing conditions and reduce the value of installment payments for the poorest (Brasil, 2016a). Beyond the new housing units, this government program intended also to improve urban infrastructure in hillside urban areas and develop urban land use reserved for ZEIS. In the case of the communities of Morro da Cruz, $40 \%$ are under this condition, since they receive less than 3 minimum wages. It is important to note that the promotion of new homes in Morro da Cruz through the PMCMV has not respected environmental

\footnotetext{
${ }^{5}$ Only in 2012 the federal legislation requires a Geotechnical Chart of Suitability for Urbanization.

${ }^{6}$ The income bands for PMCMV for the past years were: 1 (up to 3 minimum wages) 1,5; 2 (up to 6 minimum wages and band 3 up to 10 minimum wages. In 2011, based on Federal Law 12.424 (Brasil, 2011) were R\$1,395.00; Band 2: R\$ 2.790,00; Band 3: R\$ 4.650,00. In 2018, the Band 1: $\mathrm{R} \$ 1,395.00$; the Band 1,5: R\$ 2,600.00; the Band 2: R\$ 4,000.00; and Band 3: R\$ 7,000.00 (Brasil, 2019). It promoted in the country an availability of 1.51 million housing units to 5 million people since 2009 . The governmental goal is to have other 3 million people benefited in the next three years (2016-2018) (Brasil, 2016b).
} 
legislation as illustrated below, when it doesn't consider the geologic-geotechnical, geomorphological conditions.

\section{The Morro da Cruz hill in Florianópolis}

The city of Florianopolis, located on the island of Santa Catarina in Southern Brazil is endowed by environmental diversity, great natural landscape, and wellness, but the poor living conditions of a great number of inhabitants are impressive. The island's central massif called Morro da Cruz (Figure 3) is 285 meters high, being the culminating point of the central area of Florianopolis, embracing a population of about 61,899 inhabitants (15\% of the Florianopolis' total population of 421,203) (IBGE, 2011).

The island's central massif starts to be occupied in 1970's decade, when the city had a huge population growth due mainly to the migration of people from the west of Santa Catarina State looking for better living opportunities in the State Capital, Florianopolis. Like most major cities of the country, Florianopolis was not prepared to receive a huge immigration contingent and undergo such a fast and unplanned expansion that resulted in 16 informal settlements on the Morro da Cruz, built on steep slopes, with a high risk of landslides.

This massif embraces also a complex urban and ecological system, where there is a natural heritage Private Reserve (RPPN) Menino Deus with 16 ha, some public spaces, and the Municipal Natural Park (PANAMC - created in 2012), as well as four small public squares. It also has some venues of radio and television transmitters at 285 meters of altitude. With a total area of $7 \mathrm{~km}^{2}$. The 16 informal settlements are linked by zigzag streets and staircases. Additionally, tall buildings, hotels, and a hospital are surrounding the massif under a big cliff of gray granite.

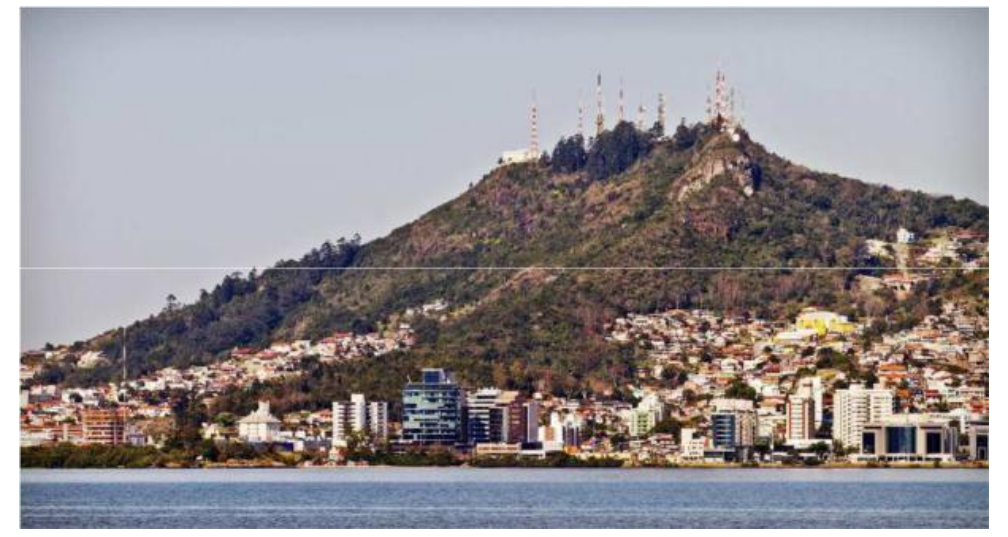

Figure 3 - Morro da Cruz cliff. Source: Rui Machado (2011).

Communities in Morro da Cruz hill have shown the lower index of urban development of Florianopolis and many are considered as "informal settlements" by the Brazilian Institute of Geography and Statistics (IBGE), the Brazilian official instance for populational data. The IBGE's official definition of informal settlements characterizes them only in terms of low income, poor housing, and lack of access to public services and might not express the real-life quality condition of the site (Kovacic \& Giampietro, 2016, p. 385).

Trying to find a better characterization for poor communities, in 2006 the SMHSA asked to CEPED-UFSC studies to provide a socioeconomic and environmental profile of families with a hierarchy of risky areas communities which evaluated housing conditions and prepared a document called "Municipal Plan for Risk Reduction - PMRR". To prepare this document the CEPED-UFSC researches the living conditions considering housing type and housing density (families and dwellers by housing unit (HU)). These indicators are supposed to define the adequate housing in Brazil and are adopted largely in the country. In relation to health and well-being, they set minimum parameters as durable construction materials, the 
existence of basic sanitary infrastructure, maximum density, exclusive sanitation, land suitability, minimum income, unwanted family coexistence (Pasternak, 2016, p. 54). The CEPED-UFSC document findings resulted defining different characterization of the informal settlements from that one defined by the IBGE (Figure 4). In 2007 the CEPED-UFSC data should be used by the SMHSA to define and implement the PAC works in impoverished urban housing and infrastructure in Morro da Cruz hill.

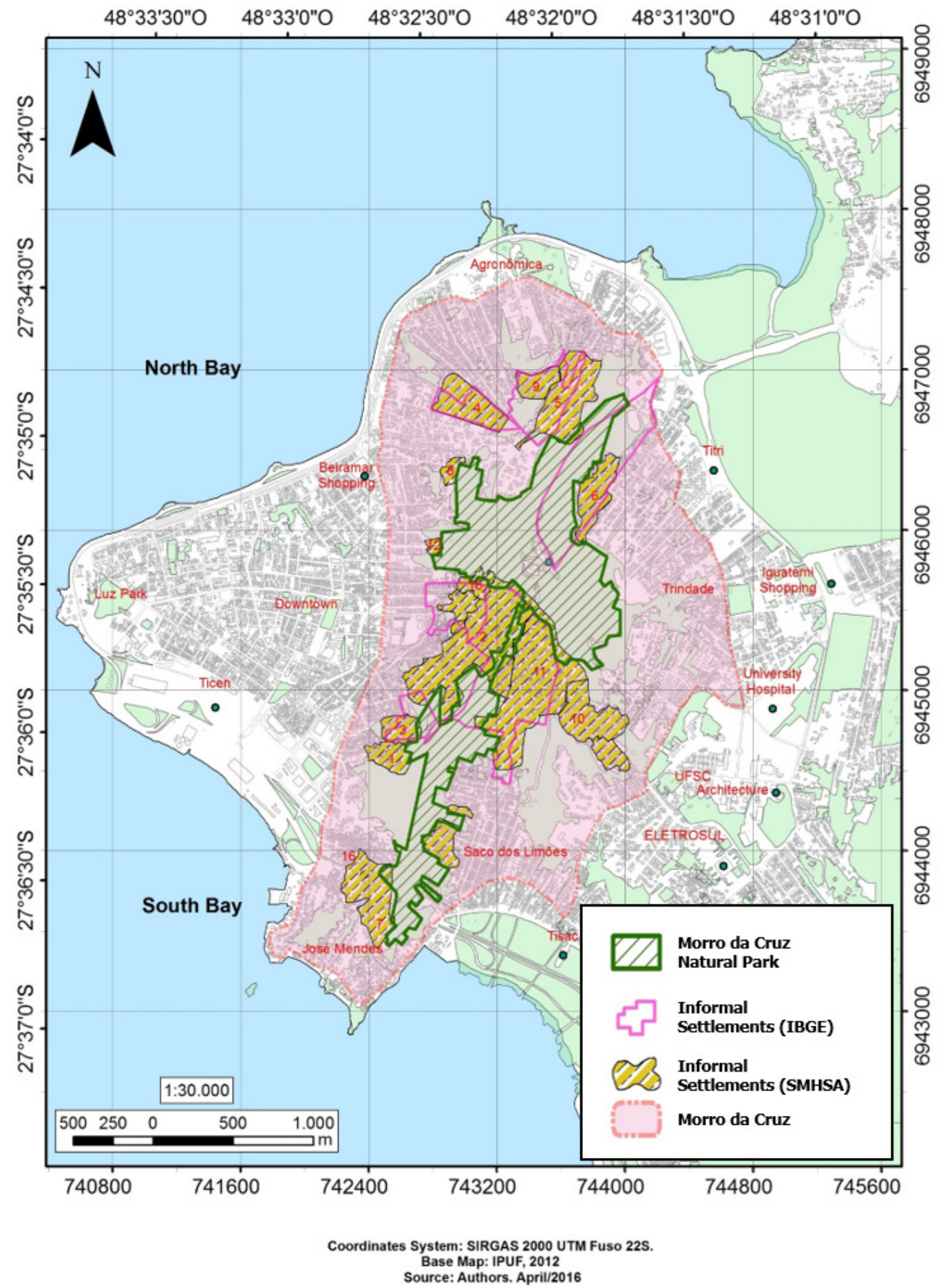

Figure 4 - Morro da Cruz informal Settlements. Source: adapted by the authors from Florianópolis (2012) and IBGE (2011). 


\section{Ceped-UFSC studies - Living conditions before PAC}

From the CEPED-UFSC studies 16 informal settlements were defined by SMHSA in Morro da Cruz: 1) Alto da Caieira 2) Penitenciária, 3) Serrinha, 4) Horácio, 5) Morro do Céu, 6) Mariquinha, 7) Queimada e Jagatá, 8) Mocotó, 9) Tico-Tico, 10) Ângelo Laporta, 11) Mont Serrat, 12) Laudelina da Cruz Lemos, 13) José Boiteux, 14) Santa Clara, 15) Morro do 25, and 16) Santa Vitória. Among these sixteen informal settlements, the Alto da Caieira was the most significant in terms of poor living conditions (Table 1). By 2004, 872 families (3,500 inhabitants) were living there (Florianópolis, 2008b) and $69 \%$ of the population has a monthly income of less than three minimum wages. This community had a massive shortage of urban infrastructure; high rate of undocumented land possession; tenure insecurity; poor living conditions; and degradation of environmentally protected areas (Florianópolis, 2007, p. 9).

Housing conditions were classified by dwellers by $\mathrm{HU}$, dormitories for $\mathrm{HU}$, density issues (more than one family for $\mathrm{HU}$, more than three people for a room), houses construction materials and finishing, and proper living conditions (Table 4).

Table 4 - Socioeconomic and environmental families profile of risk areas in Morro da Cruz informal settlements

\begin{tabular}{|c|c|c|c|c|c|c|}
\hline \multicolumn{7}{|c|}{ Housing and Living Conditions } \\
\hline $\begin{array}{l}\text { Informal } \\
\text { Settlements }\end{array}$ & $\begin{array}{c}\text { Dwellers by } \\
\text { H.U }\end{array}$ & Rooms for HU & $\begin{array}{c}\text { Density + than } \\
\text { one Family for } \\
\text { HU }\end{array}$ & $\begin{array}{l}\text { Density + 3 } \\
\text { people for } \\
\text { room }\end{array}$ & $\begin{array}{l}\text { Pauperized } \\
\text { housing }\end{array}$ & $\begin{array}{l}\text { Poor living } \\
\text { conditions }\end{array}$ \\
\hline $\begin{array}{l}\text { Alto da } \\
\text { Caieira }\end{array}$ & 5 & 4 & $43 \%$ & $48 \%$ & $68 \%$ & $62 \%$ \\
\hline Penitenciaria & 6 & 5 & $28 \%$ & $23 \%$ & $46 \%$ & $27 \%$ \\
\hline Serrinha & 4 & 5 & $34 \%$ & $37 \%$ & $47 \%$ & $44 \%$ \\
\hline Horácio & 5 & 5 & $12 \%$ & $12 \%$ & $35 \%$ & $16 \%$ \\
\hline Morro do Céu & 5 & 4 & $25 \%$ & $25 \%$ & $50 \%$ & $37 \%$ \\
\hline Mariquinha & 4 & 5 & $20 \%$ & $25 \%$ & $55 \%$ & $45 \%$ \\
\hline $\begin{array}{l}\text { Queimada e } \\
\text { Jagatá }\end{array}$ & 6 & 6 & $30 \%$ & $20 \%$ & $52 \%$ & $47 \%$ \\
\hline Mocotó & 5 & 4 & $26 \%$ & $23 \%$ & $40 \%$ & $53 \%$ \\
\hline Tico-Tico & 5 & 4 & $13 \%$ & $20 \%$ & $20 \%$ & $20 \%$ \\
\hline $\begin{array}{l}\text { Ângelo } \\
\text { Laporta }\end{array}$ & 4 & 5 & $25 \%$ & $15 \%$ & $20 \%$ & $25 \%$ \\
\hline Mont Serrat & 4 & 4 & $13 \%$ & $14 \%$ & $26 \%$ & $15 \%$ \\
\hline $\begin{array}{l}\text { Laudelina da } \\
\text { Cruz Lemos }\end{array}$ & 4 & 4 & $23 \%$ & $20 \%$ & $35 \%$ & $20 \%$ \\
\hline Jose Boiteux & 5 & 4 & $20 \%$ & $30 \%$ & $45 \%$ & $40 \%$ \\
\hline Santa Clara & 6 & 5 & $27 \%$ & $25 \%$ & $25 \%$ & $18 \%$ \\
\hline Morro do 25 & 4 & 4 & $24 \%$ & $36 \%$ & $48 \%$ & $32 \%$ \\
\hline Santa Vitória & 5 & 4 & $30 \%$ & $40 \%$ & $45 \%$ & $40 \%$ \\
\hline
\end{tabular}

Source: CEPED (UFSC, 2006 apud Florianópolis, 2007, p. 9).

The 2007's SMHSA-CEPED-UFSC report also shows (Table 5) that in these communities there were: a) high rates of households in inadequate sanitary conditions; b) informality in the access and use of electric energy/electricity; c) low or none access to water supply system; d) low or none sewerage collection; e) low or none waste collection; f) public streets without pavement; g) low or none access to public transportation (system) and; h) difficulty of mobility/accessibility.

Due to their lower rates in living conditions (Table 4 and Figure 5) as very high rates of difficult accessibility, lack of sewerage collection and households in inadequate sanitary conditions, Alto da Caieira was chosen in 2008 as a priority intervention area to receive of the Growth Acceleration Program (PAC) urban infrastructural improvements. 
Table 5 - Criteria of living conditions in Morro da Cruz before PAC interventions

\begin{tabular}{|c|c|c|c|c|c|c|c|c|}
\hline Settlements & $\begin{array}{c}\text { a) } \\
\text { Households } \\
\text { in } \\
\text { inadequat } \\
\text { e sanitary } \\
\text { conditions }\end{array}$ & $\begin{array}{c}\text { b) } \\
\text { Informality } \\
\text { in the } \\
\text { access } \\
\text { and use of } \\
\text { electric } \\
\text { energy/ele } \\
\text { ctricity }\end{array}$ & $\begin{array}{l}\text { c) Without } \\
\text { access to } \\
\text { the water } \\
\text { supply } \\
\text { system }\end{array}$ & $\begin{array}{l}\text { d) Without } \\
\text { sewerage } \\
\text { collection }\end{array}$ & $\begin{array}{l}\text { e) Without } \\
\text { waste } \\
\text { collection }\end{array}$ & $\begin{array}{l}\text { f) Without } \\
\text { pavement }\end{array}$ & $\begin{array}{l}\text { g) Without } \\
\text { access to } \\
\text { public } \\
\text { transportati } \\
\text { on (system) }\end{array}$ & $\begin{array}{l}\text { h) Difficult } \\
\text { mobility/ } \\
\text { accessibility }\end{array}$ \\
\hline \multicolumn{9}{|c|}{ (\%) } \\
\hline $\begin{array}{c}\text { Alto } \\
\text { Caieira }\end{array}$ & 29 & 44 & 48 & 69 & 32 & 58 & 71 & 87 \\
\hline $\begin{array}{c}\text { Penitenciári } \\
\mathbf{a}\end{array}$ & 15 & 12 & 33 & 54 & 45 & 41 & 35 & 42 \\
\hline Serrinha & 17 & 21 & 32 & 49 & 27 & 41 & 37 & 45 \\
\hline Horácio & 16 & 24 & 12 & 42 & 44 & 20 & 12 & 36 \\
\hline $\begin{array}{l}\text { Morro do } \\
\text { Céu }\end{array}$ & 25 & 25 & 12 & 45 & 37 & 14 & 11 & 22 \\
\hline Mariquinha & 25 & 25 & 45 & 81 & 65 & 71 & 85 & 80 \\
\hline $\begin{array}{l}\text { Queimada } \\
\text { e Jagatá }\end{array}$ & 36 & 24 & 42 & 72 & 42 & 46 & 24 & 49 \\
\hline Mocotó & 26 & 20 & 36 & 86 & 47 & 63 & 36 & 40 \\
\hline Tico-Tico & 13 & 13 & 13 & 37 & 43 & 33 & 20 & 33 \\
\hline $\begin{array}{l}\text { Ângelo } \\
\text { Laporta }\end{array}$ & $\begin{array}{l}\text { Without } \\
\text { info }\end{array}$ & $\begin{array}{l}\text { Without } \\
\text { info }\end{array}$ & $\begin{array}{c}\text { Without } \\
\text { info }\end{array}$ & 25 & 12 & $\begin{array}{l}\text { Without } \\
\text { info }\end{array}$ & 14 & 15 \\
\hline $\begin{array}{l}\text { Mont Serrat } \\
\text { Laudelina }\end{array}$ & 8 & 13 & 22 & 39 & 37 & 19 & 15 & 39 \\
\hline $\begin{array}{l}\text { da Cruz } \\
\text { Lemos }\end{array}$ & 20 & 17 & 20 & 45 & 40 & 14 & 21 & 36 \\
\hline $\begin{array}{c}\text { Jose } \\
\text { Boiteux }\end{array}$ & 40 & 20 & 18 & 40 & 45 & 20 & 15 & 45 \\
\hline $\begin{array}{l}\text { Santa } \\
\text { Clara }\end{array}$ & 25 & 14 & 25 & 50 & 37 & 15 & 18 & 38 \\
\hline $\begin{array}{l}\text { Morro do } \\
25\end{array}$ & 18 & 20 & 16 & 60 & 40 & 22 & 16 & 46 \\
\hline $\begin{array}{l}\text { Santa } \\
\text { Vitória }\end{array}$ & 20 & 26 & 26 & 63 & 46 & 66 & 20 & 60 \\
\hline
\end{tabular}

Source: adapted by the authors from CEPED (UFSC, 2006 apud Florianópolis, 2007, p. 11-13).

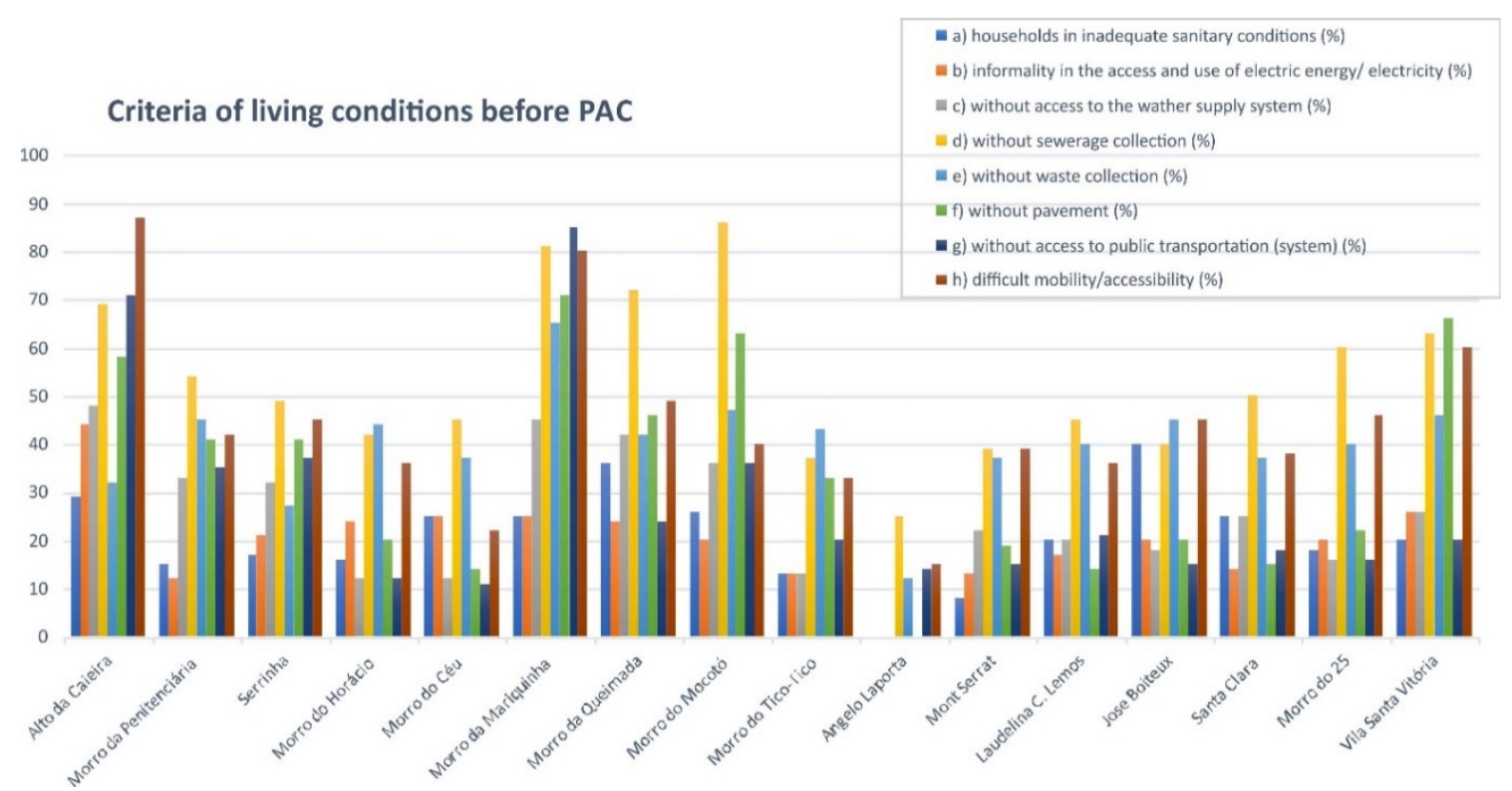

Figure 5 - Criteria of living conditions in Morro da Cruz before PAC interventions. Source: adapted by the authors from CEPED (UFSC, 2006 apud, Florianópolis, 2007, p. 11-13). 


\section{Land use and social housing}

Risk Cartography is a mapping tool directed to better equip civil society for reflexive risk governance, aiming at an integrative and multi-perspective knowledge platform to deal with risk controversies and to open the debate for civil society and for better decision making and knowledge-based regulation (Mapping controversies website, April 2017). When the PAC interventions in the Morro da Cruz occurred in 2009, neither the risk cartography nor the ZEIS definitions were settled. Later, in 2014 the risk cartography will be partially used, but redefined by the new Florianopolis Master Plan (PMF, Municipal Law 482, 2014) to allow ZEIS consolidation at Morro da Cruz.

The risk cartography of Morro da Cruz (geomorphology, morphology, slope and drainage) confirmed that this hill is environmentally fragile, unable to stand unplanned occupation. Despite several recommendations, the most sensitive environmental areas (rocky outcrops, a field of boulders, residual diabase soil, unfavorable morphology or native vegetation) continue to be occupied. In his research, Rego Neto (1987) integrates an analysis of environmental factors, evaluating environmental characteristics and conditions of "Morro da Cruz" slopes, in Florianopolis, Santa Catarina state, Brazil.

After an analysis of geologic-geotechnical \& geomorphological conditions and of the existing vegetation and occupation a "qualitative overlay" technique was applied to the data to achieve a map of recommended land uses, which could support a rational planning. Some of those areas of Morro da Cruz appear in Rego Neto's study as a remarkable environmental non-exploitation area surrounded by land use restricted areas and none capable of urbanizing (Figure 6). Rego Neto's showed that only $1 / 3$ of the total area of Morro da Cruz is adapted to urbanization.

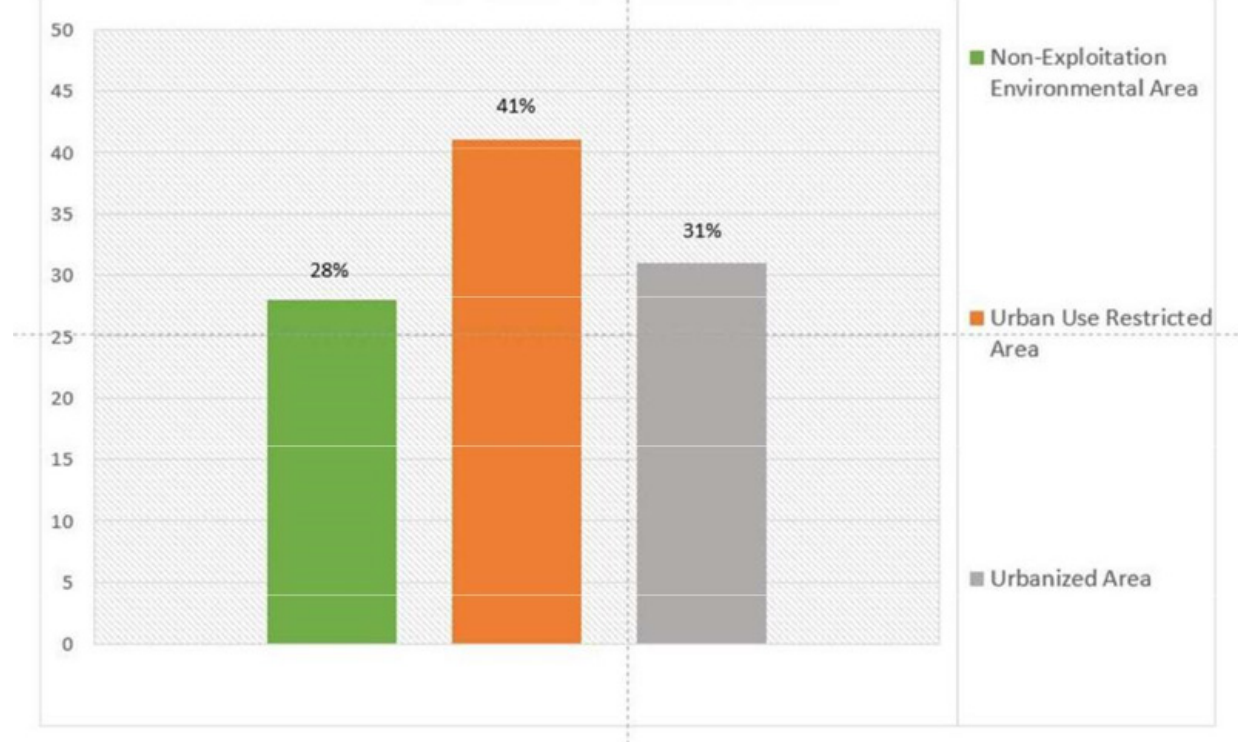

Figure 6 - Land Use in Morro da Cruz. Source: adapted by the authors from Rego Neto (1987).

The current risk classification used by the Municipality, unfortunately, does not provide enough parameters for sustainability, what confirms the importance of the role of the risk cartography as restrictive parameters for urban development. In dealing with the dynamics of coastal environmental landscapes and the protection of risk areas, Cruz (1998, p. 245-247) states that "coastal risk areas" (more vulnerable to erosion processes) should not be categorically occupied, of aggravating their situation and suffering greater damage.

Nowadays, there is a Municipal Plan for Risk Reduction (PMRR from CEPED, UFSC, 2006) that allows implementing structural and non-structural actions in landslide risky settlements. For Morro da Cruz settlements, the recommendation from PMRR is not encouraging the occupation process and permanent monitoring to prevent landslides accidents. 
Also, the Urban Planning Institute of Florianopolis - IPUF defined Morro da Cruz informal settlements as "Special Social Interest Zones - ZEIS" within the city Master Plan (Florianópolis, 2014) aiming to decrease dwellers social vulnerability.

In Morro da Cruz, the ZEIS have been implemented since 2005 supported by a former Master Plan dated from 1998. The informal settlement of Serrinha won this status in 2005, allowing the start of the process regularization of land tenure. After the beginning of this process, the land and rental prices increased and without governmental control, residents benefited by the land tenure regulation started to sell or rent their houses and moved to surrounding neighborhoods with lower land prices as Alto da Caieira. This also triggered the occupation of the environmental non-exploitation area of Morro da Cruz.

Even though the 1998 Master Plan had defined "Preservation Areas with Limited Use" - APL and "Predominantly Residential areas" - ARP-0 (characterized by land sliding risk and fragile vegetation) (Figure 7), most of these areas are also designed as ZEIS in the 2014 Master Plan and start to receive social housing units.

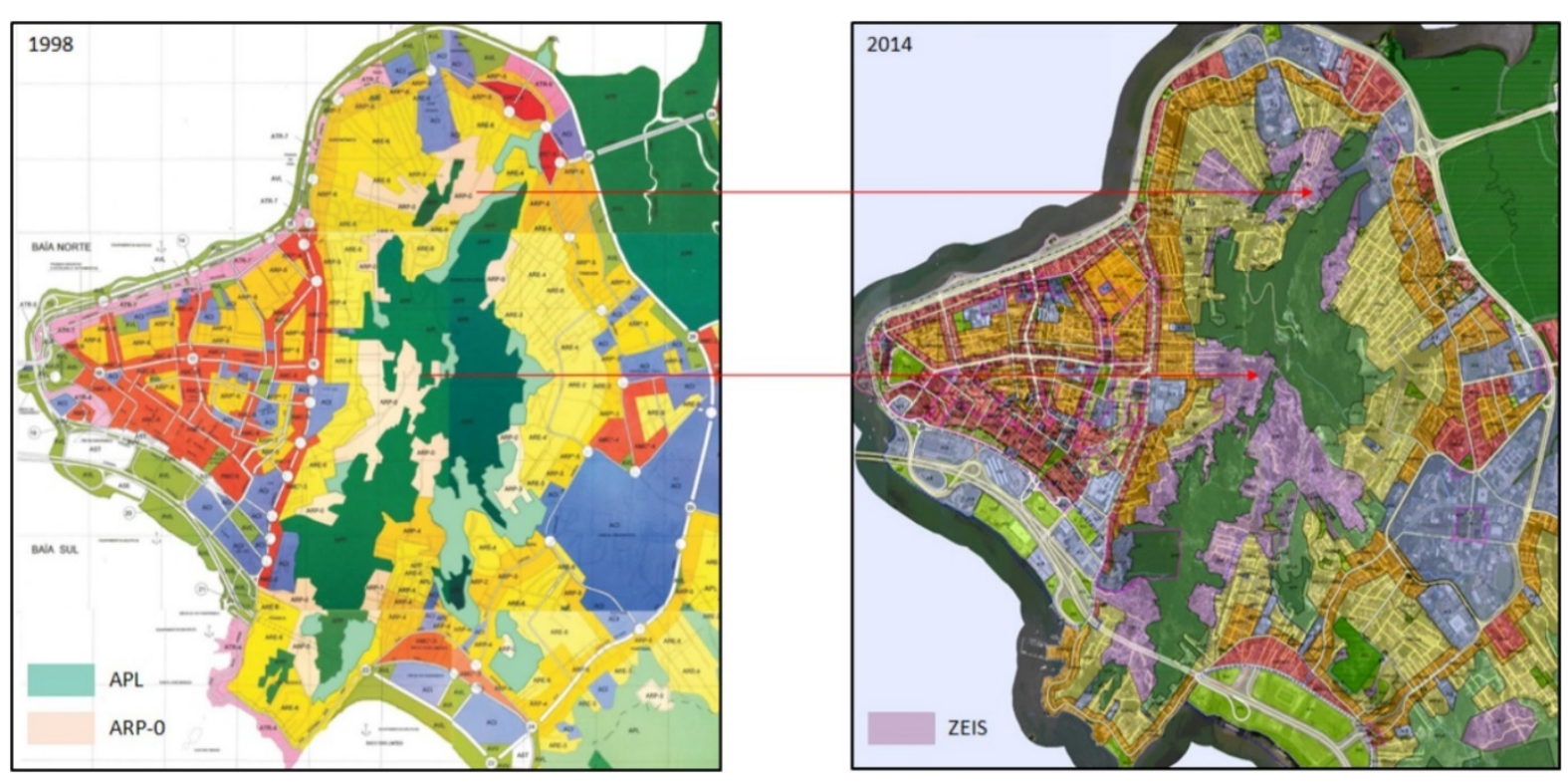

Figure 7 - The conversion of APL and ARP-0 to ZEIS in Florianópolis Master Plans. Sources: Florianópolis, Master Plan (Florianópolis, 1998). Florianópolis, Master Plan (Florianópolis, 2014).

The conversion of APL (leisure public areas) in the Florianópolis Master Plan (Florianópolis, 1998) to ZEIS in the Master Plan (Florianópolis, 2014) shows a change of political/local administration guidelines/interests.

In 2012 an environmental zoning plan for the Morro da Cruz was elaborated and approved by FLORAM (Municipal Secretary of Environment). It has a natural park with buffer zone where the urban uses should be restricted (Figure 8). It also considered the risk areas defined by IPUF in a geotechnical chart (Rego Neto \& Rosa Filho, 1986) but did not avoid the continuous suppression of the remaining forest fragments nor the implementation of ZEIS in risk areas (Figure 9) (Florianópolis, 2012). 


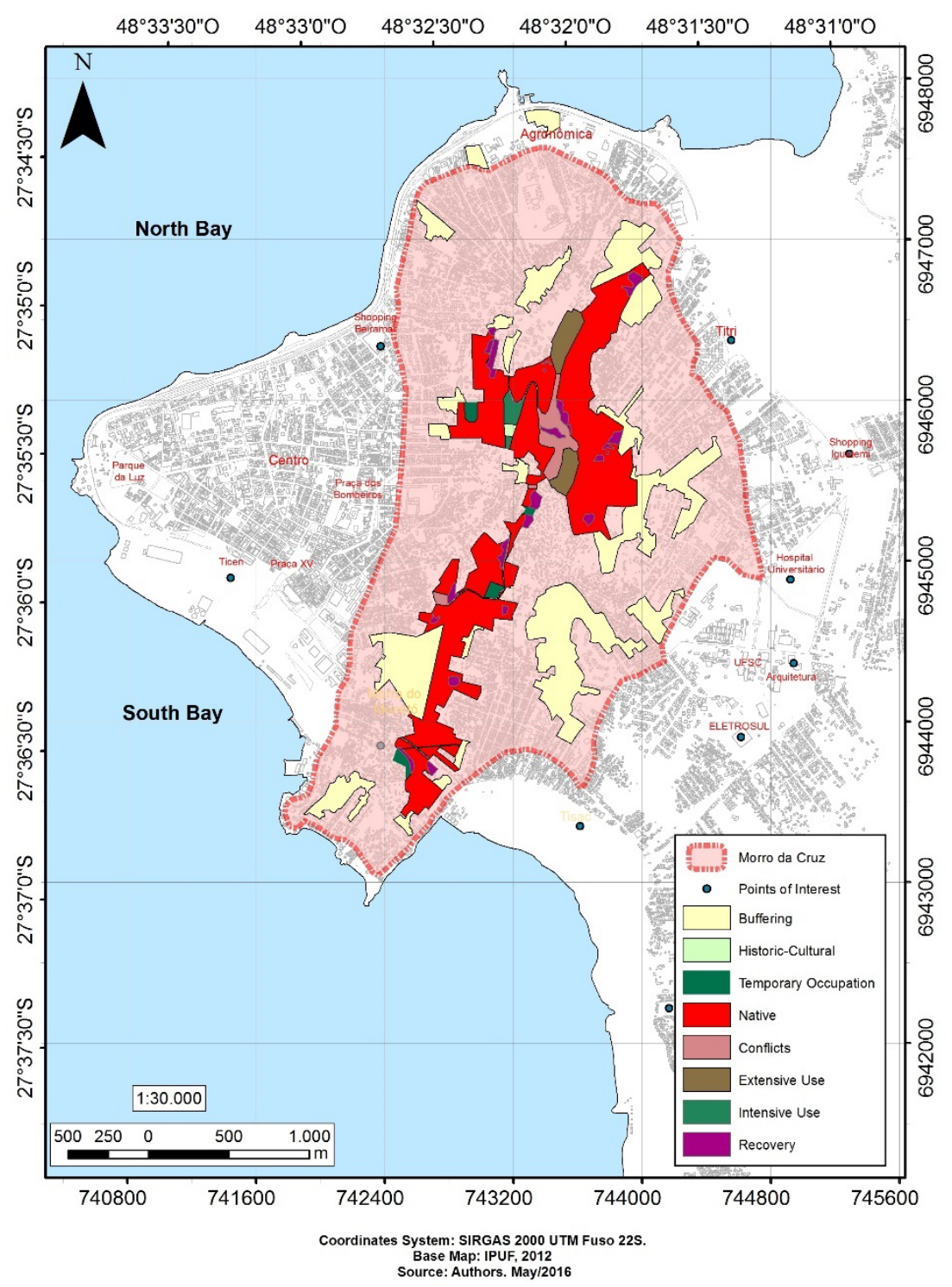

Figure 8 - Morro da Cruz environmental zoning. Source: adapted by the authors from Florianópolis (2012, p. 23). 


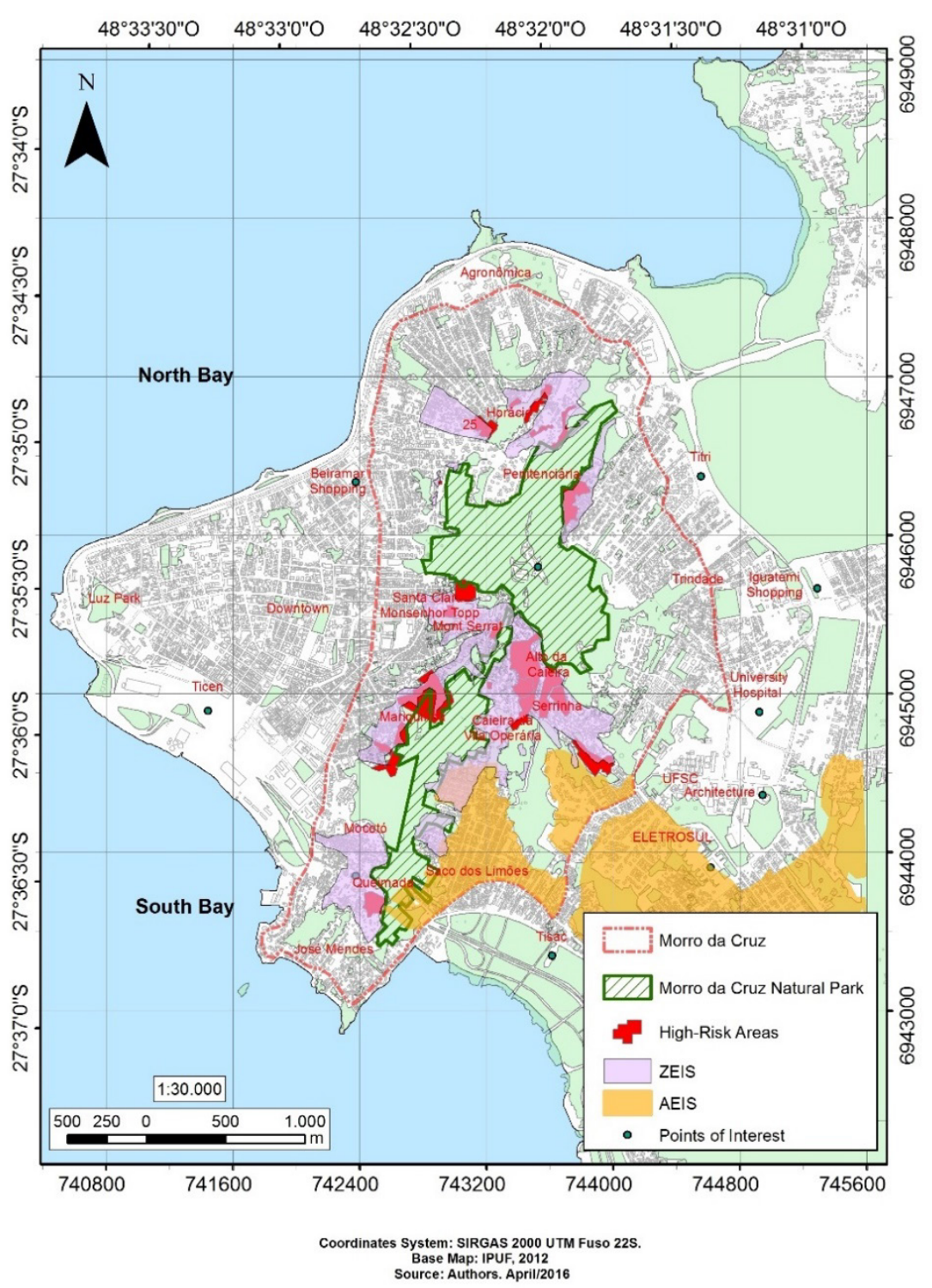

Figure 9 - ZEIS and High-Risk Areas of Morro da Cruz. Source: adapted by the authors from Florianópolis (2012).

Also, some social housing implemented in Morro da Cruz by the Municipality following the ZEIS directives in 2012 Municipal Master Plan pushed the limits of the conservation unit Morro da Cruz Municipal Natural Park (PANAMC), set up also in 2012. High-risk areas and ZEIS location are overlaid (Figure 9) what allow future housing projects would be implemented in those areas.

Despite the legislation, new illegal residential occupations also happened in areas designated as ZEIS in Alto da Caieira. This resulted aggressive actions by the Municipality to remove these shacks from such areas (Figure 10). 


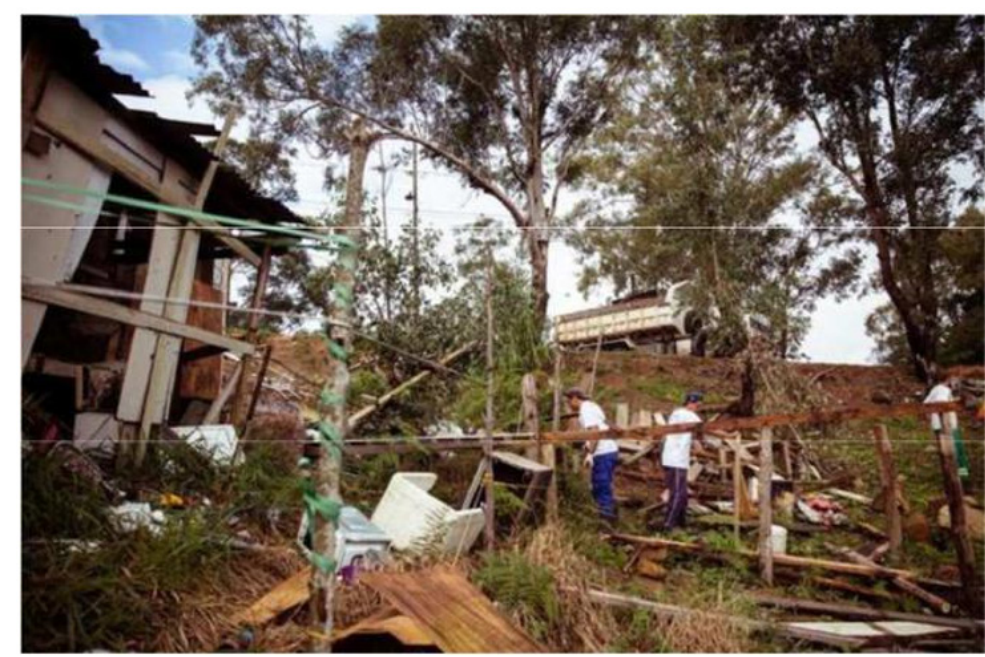

Figure 10 - Houses removal in Alto da Caieira. Source: Pandini (2017 June).

\section{Recent interventions}

The PMCMV supposed to develop designed ZEIS areas, but at Morro da Cruz this happened partially and did not follow the approved propose. Despite the budget prevision for housing units be meaningful (Figure 11) and forecast the construction of 438 residential units, after 5 years from its first intervention (2009) only 123 residential units were financed by the PMCMV (PMF, 2011-2014).

The budget outlook Florianópolis (2007) distributed the resources among to the following areas: housing, sanitary modules; water and sewage network, retaining walls, paving electrical network, drainage, vertical transportation system, social work, urban park, land tenure regularization, supervision works, projects, earthworks, community equipment, solid waste-garbage. According to this initial budget $36 \%$ should be directed to housing, $9 \%$ to containment and $2 \%$ to land tenure regularization
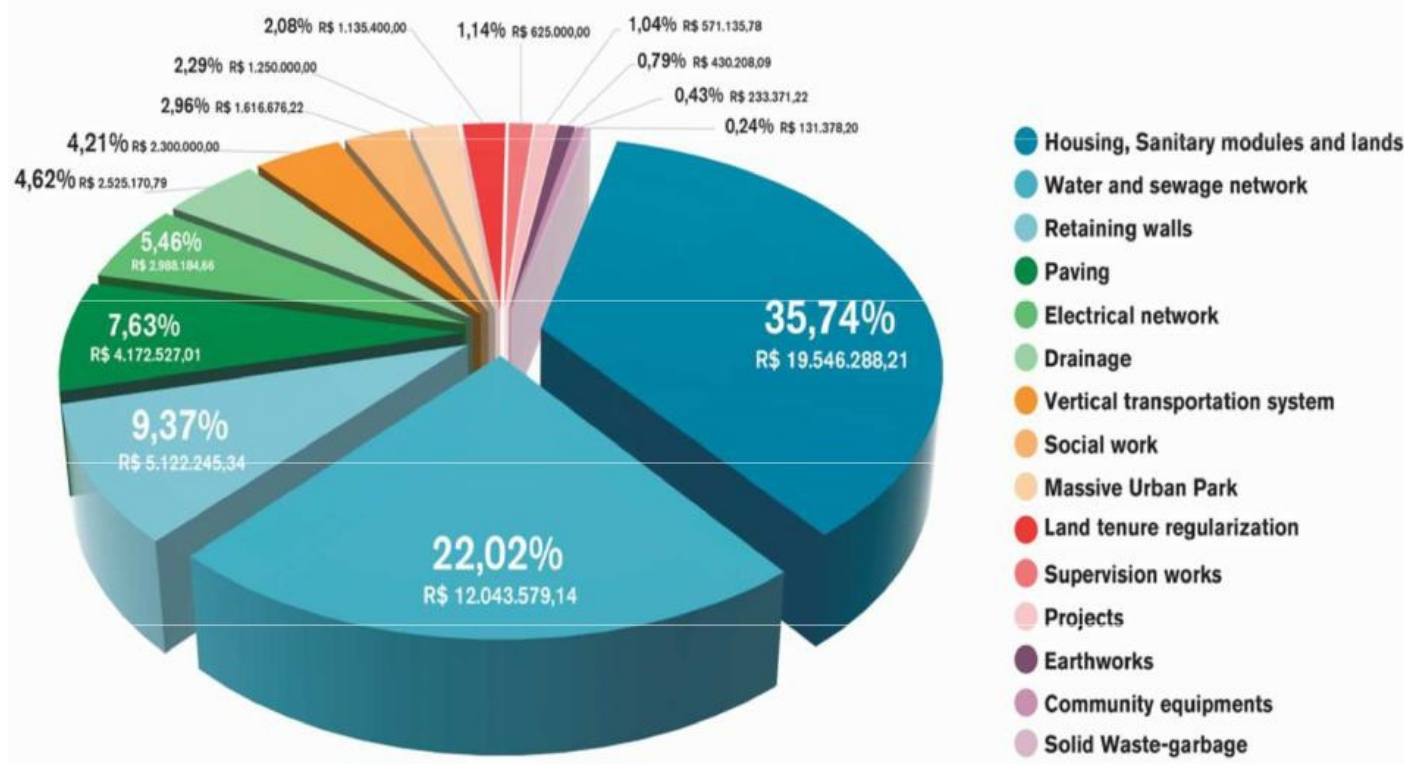

Figure 11 - PAC's investments preview for Morro da Cruz. Source: adapted by the authors from Florianópolis (2007).

The Municipal Administration chose to use the funds from PAC to improve the infrastructure at Morro da Cruz rather than build new residential units. At the Morro da Cruz, the interventions basically 
consisted of paving some streets, building retaining walls and the providing sewerage, water supply system and drainage. The road improvements provided an interconnection with the neighboring informal settlements such as Alto da Caieira, Mont Serrat and Serrinha.

In 2011, housing deficit was 438 houses for the whole Morro da Cruz (Figure 12) where labels and arrows refer to A: Morro do Céu; B: Mont Serrat/Nova Descoberta; and C: Alto da Caieira, respectively. By that year, thirty units of social housing were built in Morro da Cruz, inside the informal settlements of Morro do Céu and Mont Serrat (Figures 13 and 14).

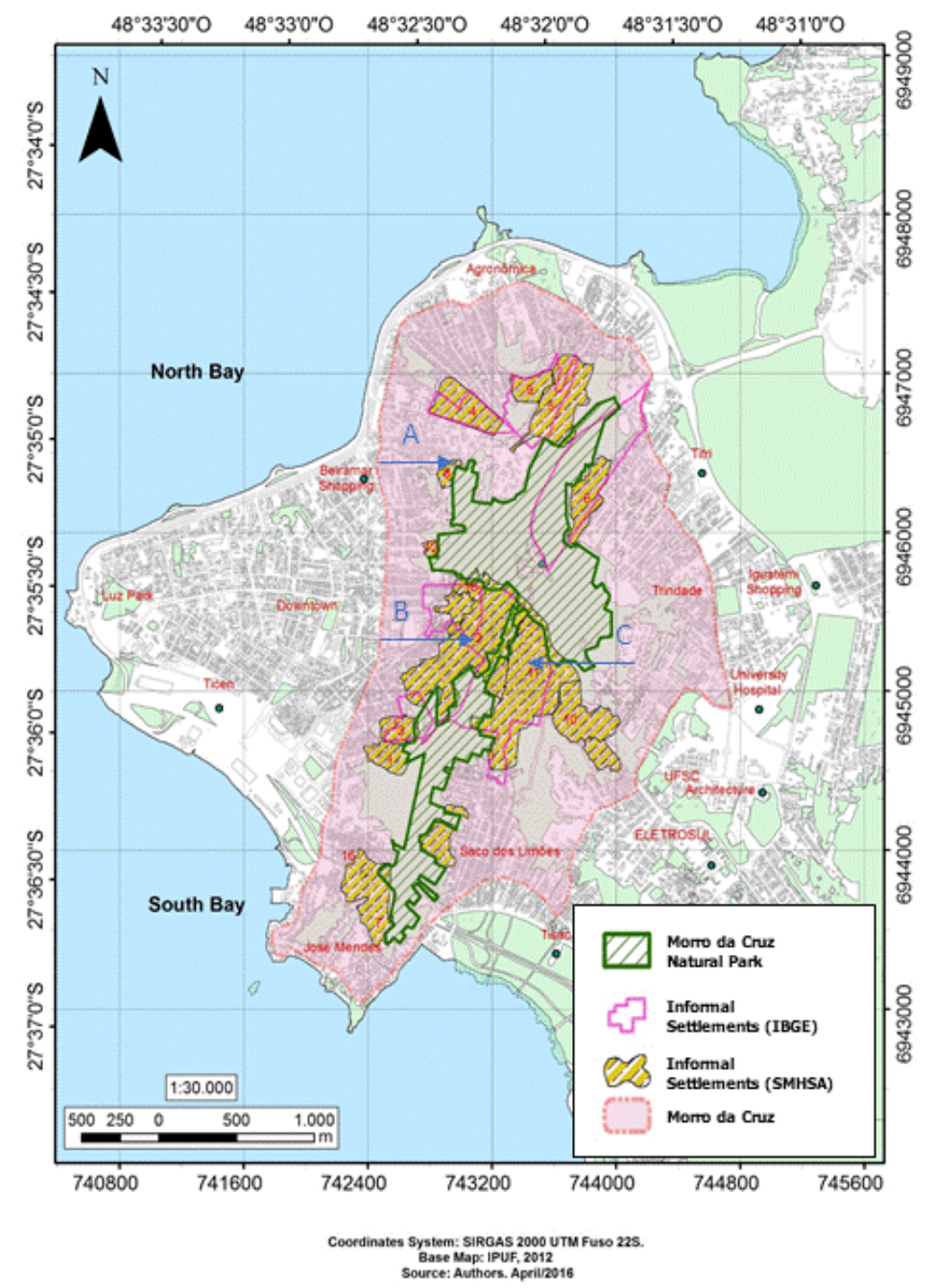

Figure 12 - Projects of Houses - Morro da Cruz. Source: adapted by the authors from Florianópolis (2012). 

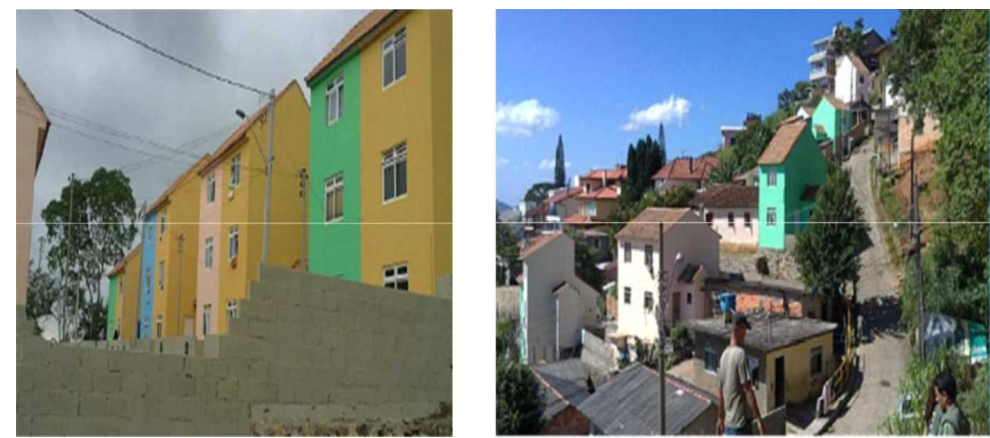

Figure 13 - Projects of Houses - Morro do Céu (location: arrow A on Figure 12). Source: Secretary of Housing and Environmental Sanitation-SMHSA (Florianópolis, 2011).

Later, in 2014, the informal settlements of Mont Serrat (Figure 14) and Horacio received 50 houses units. The Morro da Cruz's housing deficit in 2016 was approximately 400 units including into this account the dwellings under land sliding risk, in the social rental regime and inside the environmental non-exploitation areas.

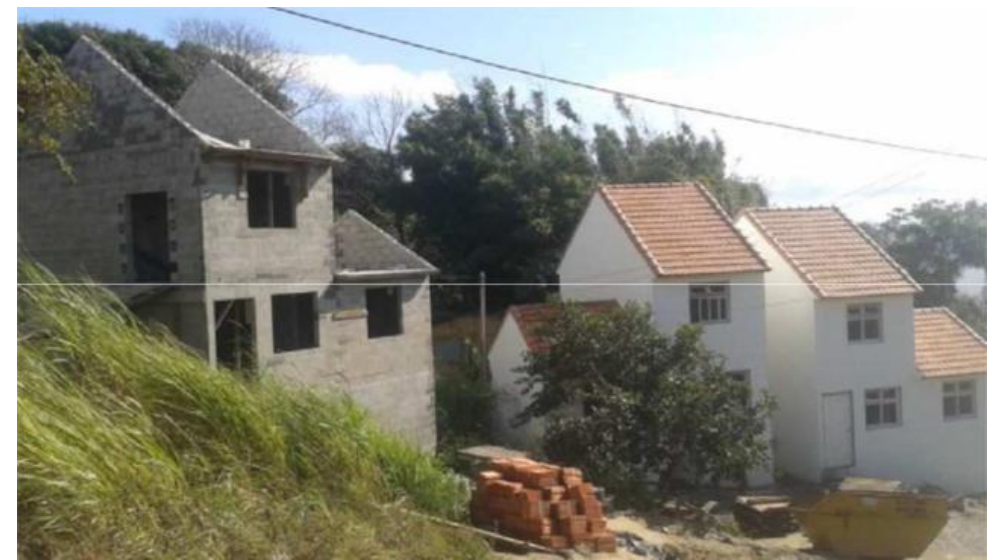

Figure 14 - Social housing in Mont Serrat/Nova Descoberta (location: arrow B on Figure 12). Source: Florianópolis (2014).

From 2011 to 2014123 houses were built in the Morro da Cruz, only 5\% of them were in Alto da Caieira, the most impoverished informal settlement. Alto da Caieira had $15 \%$ of the whole population of Morro da Cruz in 2011 and 35\% of them at landslide risks. At Mont Serrat informal settlement the new houses built by the government were located close to the natural park of Morro da Cruz and outside the ZEIS zone limits established by the Master Plan and into a land sliding high-risk area. By 2016 none of the social housing projects are concluded, the vertical transportation system foreseen was not implemented nor the land tenure regularization was finished. The community equipments are partially constructed (the health care center of Alto da Caieira, for example) and still there are invasions.

Also, in 2016, political changes occurred and brought difficulties to keep coherence between government tiers and to cope with housing deficit in the Morro da Cruz communities, since the Municipal Construction Department takes place of the Municipal Housing and Environmental Sanitation Secretary. An overall scenario was depicted by CGU7 in 2016: its report on the final works showed the total amount invested in Morro da Cruz, Florianópolis was $\mathrm{R} \$ 94,542,625.45$. This amount represent an increase of $42 \%$ on the amount invested at the beginning of the works (Figure 15). More than this, the CGU examined the retaining walls built in Morro da Cruz and concluded that the application of federal resources was not adequate because the execution information given in the project was quite different from those in the calculation memories.

${ }^{7} \mathrm{CGU}$ - Federal Finance Control is responsible for public patrimonial defense, budget transparency and corruption fight. 


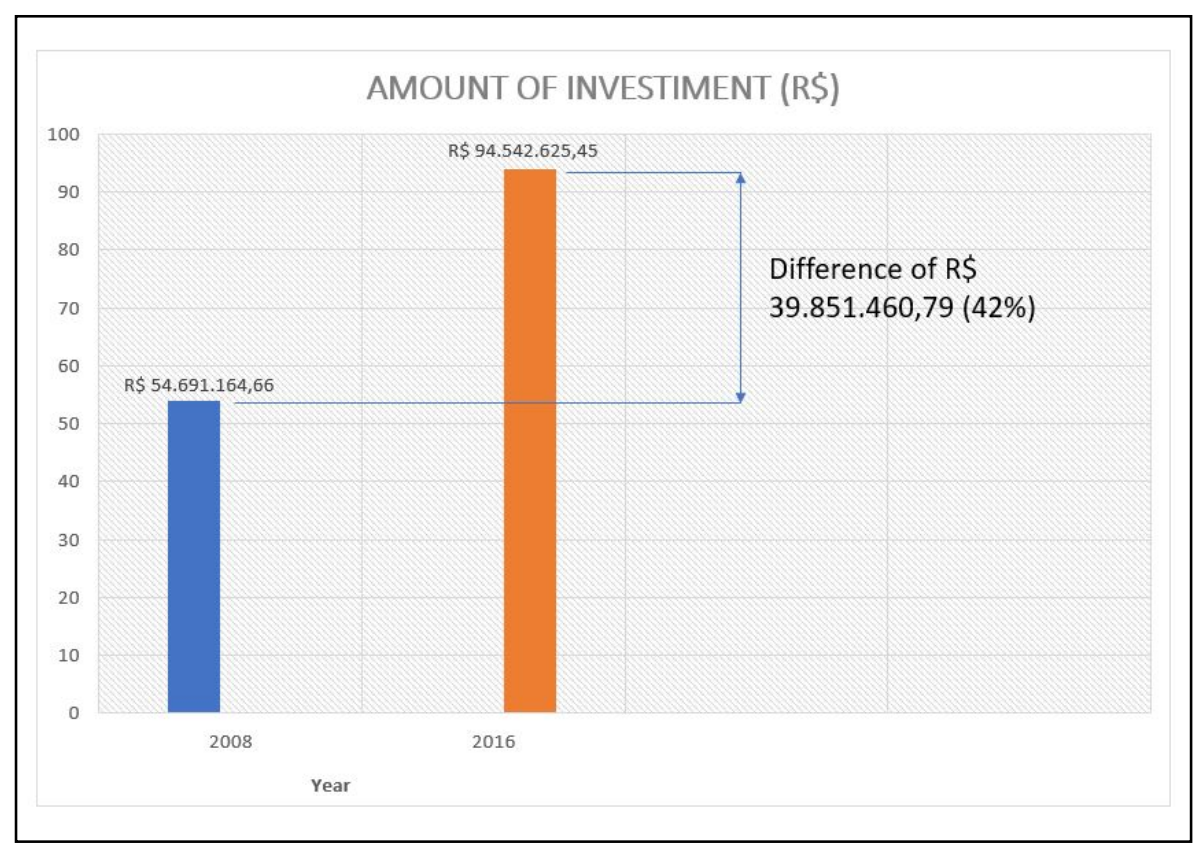

Figure 15 - Amount of investment (2008 and 2016). Source: compared by authors from Florianópolis (2008a) and Brasil (2016c).

To better understand the processes developed in the Morro da Cruz's occupation, a timeline is provided here to show the different times between law approvals and projects implemented with PAC in Morro da Cruz (Figure 16). In this graphic we can observe that housing projects were implemented from 2011 to 2016 meanwhile the Master Plan defined ZEIS areas in 2014. The local social housing plan was only approved in 2012, after the social housing projects in Morro da Cruz had already started. The timeline of federal and local law approvals, programs and projects implemented (2001 to 2016) can clearly show the dissonance between federal guidelines and local projects.

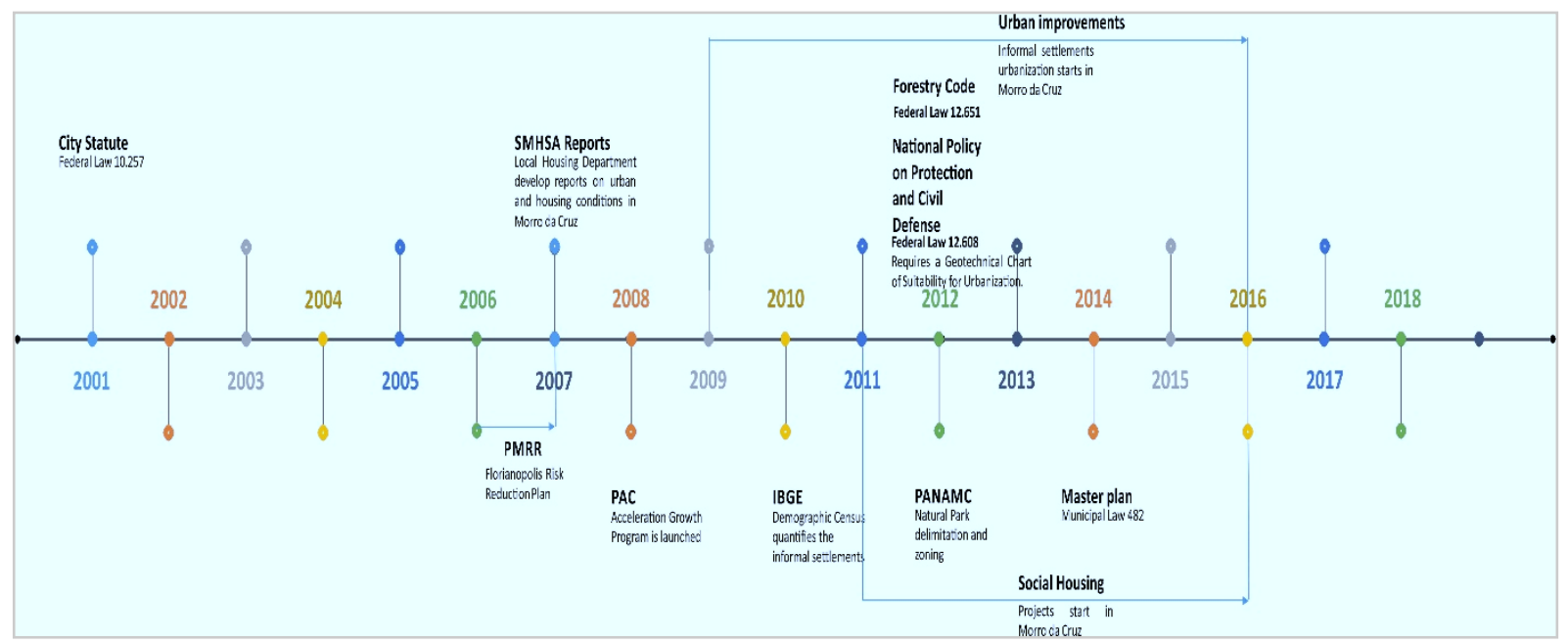

Figure 16 - Timeline of federal and local law approvals, programs and projects implemented (2001 to 2016 ). Source: The authors.

\section{Concluding remarks}

This discussion tries to find out to what extend different tiers of Government responses might be effective to promote better life quality, decrease risks related to landslide and respond to housing deficit. 
The complex legal and political environment in Brazil challenged us to pursue different processes that drove Governmental actions success and failures on setting up the mechanisms aimed at protecting and developing informal urbanization on slopes.

Although our study recognizes positive aspects of the improvements made by PAC in the Morro da Cruz informal settlements, it also criticizes the way they were implemented, contradicting previous studies and establishing an unfair and not effective use of urban land regulation and development instruments (Table 6).

Table 6 - Government responses to urban and environmental related issues

\begin{tabular}{|c|c|c|c|}
\hline $\begin{array}{l}\text { Urban and } \\
\text { environmental }\end{array}$ & Related issues & $\begin{array}{l}\text { Governmental } \\
\text { response }\end{array}$ & Success (in 2017) \\
\hline SOCIAL HOUSING & Housing Deficit & $\begin{array}{l}\text { New houses } \\
\text { construction } \\
\text { Land tenure } \\
\text { regularization } \\
\text { Resettlements of } \\
\text { houses in risk }\end{array}$ & $\begin{array}{c}\text { Partial. Despite a number of new social } \\
\text { housing constructed, many threats natural } \\
\text { park and many has been located at landslide } \\
\text { risk zone. The number of houses did not reach } \\
\text { housing deficit. } \\
\text { Partial. land tenure regularization not } \\
\text { concluded. } \\
\text { Fail. No action on this directive. }\end{array}$ \\
\hline ENVIRONMENT & Biodiversity conservation & $\begin{array}{l}\text { Reforestation / } \\
\text { Preservation } \\
\text { Monitoring } \\
\text { Demolishing } \\
\text { |llegal Houses }\end{array}$ & $\begin{array}{l}\text { Partial. } 1998 \text { Master Plan -Preservation Areas } \\
\text { with Limited Use and Morro da Cruz Municipal } \\
\text { Natural Park - 2012. Though, new social } \\
\text { housing constructed threats natural park. } \\
\text { Fail. No system to monitor protected areas. } \\
\text { Yes. Recent demolition. }\end{array}$ \\
\hline INFRASTRUCTURE & $\begin{array}{l}\text { Disaster mitigation/risk } \\
\text { reduction/qualified } \\
\text { urbanization }\end{array}$ & $\begin{array}{l}\text { Containment } \\
\text { works } \\
\text { Mobility/Road } \\
\text { paving } \\
\text { Drainage system }\end{array}$ & $\begin{array}{l}\text { Partial. Doubts about proper use of the } \\
\text { budget. } \\
\text { Partial. Vertical transportation system foreseen } \\
\text { not implemented. Paving almost totally } \\
\text { concluded. } \\
\text { Yes. Totally implemented according to initial } \\
\text { plans. }\end{array}$ \\
\hline
\end{tabular}

Source: The authors.

Despite PAC's investments preview for Morro da Cruz (Figure 11) prioritize building of new houses (36\% of total amount) and housing improvements with sanitary modules, $72 \%$ of the initial (Florianopolis, 2008b) housing deficit inside informal settlements weren't targeted. Few risk susceptible residents were removed from their houses but still there are several houses in unsuitable urbanization areas.

Brazilian Institute of Geography and Statistics (IBGE) considers inadequate a house at landslide risks but does not consider as part of housing deficit. Despite this, building new houses for the poor under land sliding risks was considered the most important public intervention by studies commissioned to the CEPED-UFSC by the SMHAS to be done in the Morro da Cruz massif.

Opposing to the study, interventions implemented in Morro da Cruz (from 2009-2016) prioritized paving some streets, building retaining walls, sewerage and water supply system and drainage, belvederes, new streets and avenues. In short, interventions in charge of SMHSA did not match to priorities addressed by reports done in 2007 and 2008. Instead of relocating risky houses, the government infrastructural interventions (PAC) maintained most of these residents in their houses, trying to provide them better-living conditions. Only $28 \%$ of the new safe houses needs of Morro da Cruz was reached showing mismatches between original goals of the PAC program with the city's Master Plan directives.

Improvements of this new urban infrastructure also promoted a non-planned expansion of a residential land use that grew up fast all along new roads implemented after 2009. Unfortunately, the improvements did not avoid land speculations. 
Other important issue pointed out in our study is the lack of consideration to risk cartography and the conversion of APL (leisure public areas) in ZEIS for building of new social housing in Morro da Cruz causing both, loss of green spaces and further actions to contain landslides, increasing housing budget.

Discussions done here suggested a need to overcome a mismatch between the solely technical-based interventions and real needs of poor population. The mismatch between the Federal Programs and Municipal directives did not collaborate in this case for proper use of public resources in risky landslide areas. In addition, mismatches between studies perspectives and actions implemented should be reviewed to better planning effectiveness.

Therefore, a reformulation of urban planning approaches and practices to better consider the rights to the city under sustainable standards is needed. Long-term urban and planning management do need to follow geo-environmental studies to establish restrictions and conditions to urban land use restricted areas.

The perspectives discussed here emphasize rational use of urban legal strategies and instruments to promote social justice and raise cities life quality, reducing land-sliding risks. Also, a better interconnection and synchronicity among several tiers of Government is a major challenge to develop urban planning for low-income and landslide risky areas.

\section{REFERENCES}

Avila, M. R. R., \& Mattedi, M. A. (2017). Desastre e território: a produção da vulnerabilidade a desastres na cidade de Blumenau/SC. Urbe. Revista Brasileira de Gestão Urbana, 9(2), 187-202. http://dx.doi.org/10.1590/21753369.009.002.ao03.

Bonduki, N. G. (1998). Origens da habitação social no país. São Paulo: Estação Liberdade.

Brasil. (2001a, 10 de julho). Lei no 10.257, de 10 de julho de 2001. Regulamenta os arts. 182 e 183 da Constituição Federal, estabelece diretrizes gerais da política urbana e dá outras providências [Federal Law 10,257, 10 July 2001. City statute]. Brasília: Diário Oficial da União. Retrieved in 2016, July 20, from http://www.planalto.gov.br/ccivil_03/leis/leis_2001/l10257.htm

Brasil. (2001b, 12 de fevereiro). Lei no 10.188, de 12 de fevereiro de 2001. Cria o Programa de Arrendamento Residencial, institui o arrendamento residencial com opção de compra e dá outras providências [Federal Law 10.188, de 12 February 2001. Residential Leasing Program]. Brasília: Diário Oficial da União. Retrieved in 2017, March 22, from http://www.planalto.gov.br/ccivil_03/LEIS/LEIS_2001/L10188.htm

Brasil. (2009, 7 de julho). Lei no 11.977, de 7 de julho de 2009. Dispõe sobre o Programa Minha Casa, Minha Vida PMCMV e a regularização fundiária de assentamentos localizados em áreas urbanas; altera o Decreto-Lei no 3.365, de 21 de junho de 1941, as Leis nos 4.380, de 21 de agosto de 1964, 6.015, de 31 de dezembro de 1973, 8.036, de 11 de maio de 1990, e 10.257, de 10 de julho de 2001, e a Medida Provisória no 2.197-43, de 24 de agosto de 2001; e dá outras providências [Federal Law 11,977, 7 July 2009. My house, my life. Acceleration Growth Program - PAC's subprogram]. Brasília: Diário Oficial da União. Retrieved in 2018, September 11, from http://www.planalto.gov.br/ccivil_03/_ato2007-2010/2009/lei/L11977compilado.htm

Brasil. (2011, 16 de junho). Lei 12.424/2011 de 16 de junho de 2011. Altera a Lei no 11.977, de 7 de julho de 2009, que dispõe sobre o Programa Minha Casa, Minha Vida - PMCMV e a regularização fundiária de assentamentos localizados em áreas urbanas, as Leis $n^{\circ}$ s 10.188, de 12 de fevereiro de 2001, 6.015, de 31 de dezembro de 1973, 6.766, de 19 de dezembro de 1979, 4.591, de 16 de dezembro de 1964, 8.212, de 24 de julho de 1991, e 10.406, de 10 de janeiro de 2002 - Código Civil; revoga dispositivos da Medida Provisória no 2.197-43, de 24 de agosto de 2001; e dá outras providências [Federal Law no 12,424]. Brasília: Diário Oficial da União. Retrieved in 2016, December 20, from http://www.planalto.gov.br/ccivil_03/_Ato2011-2014/2011/Lei/L12424.htm

Brasil. (2012a, 10 de abril). Lei no 12.608, de 10 de abril de 2012. Institui a Política Nacional de Proteção e Defesa Civil - PNPDEC; dispõe sobre o Sistema Nacional de Proteção e Defesa Civil - SINPDEC e o Conselho Nacional de Proteção e Defesa Civil - CONPDEC; autoriza a criação de sistema de informações e monitoramento de desastres; altera as Leis $n^{\circ}$ s 12.340, de 1ํo de dezembro de 2010, 10.257, de 10 de julho de 2001, 6.766, de 19 de dezembro de 
1979, 8.239, de 4 de outubro de 1991, e 9.394, de 20 de dezembro de 1996; e dá outras providências [Federal Law 12,608, 10 April 2012. Natural disaster management]. Brasília: Diário Oficial da União. Retrieved in 2016, February 02, from http://www.planalto.gov.br/ccivil_03/_Ato2011-2014/2012/Lei/L12608.htm

Brasil. (2012b, 25 de maio). Lei no 12.651, de 25 de maio de 2012. Dispõe sobre a proteção da vegetação nativa; altera as Leis $n^{\circ}$ S 6.938, de 31 de agosto de 1981, 9.393, de 19 de dezembro de 1996, e 11.428, de 22 de dezembro de 2006; revoga as Leis no-s 4.771, de 15 de setembro de 1965, e 7.754, de 14 de abril de 1989, e a Medida Provisória $n^{-}$ 2.166-67, de 24 de agosto de 2001; e dá outras providências [Federal Law 12,651, 25 May 2012. Forestry code]. Brasília: Diário Oficial da União. Retrieved in 2016, March 05, from http://www.planalto.gov.br/ccivil_03/_Ato2011-2014/2012/Lei/L12651.htm

Brasil. (2016a). Brazilian government's main programs. Brasília: Brazil Gov News. Retrieved in 2016, August 08, from http://www.brazilgovnews.gov.br/federal-government/social-programs

Brasil. Ministério do Planejamento Orçamento e Gestão. (2016b). Relatório brasileiro para a Habitat III. Brasília: Instituto de Pesquisa Econômica Aplicada. Retrieved in 2016, August 03, from habitat3.org/wpcontent/uploads/National-Report-LAC-Brazil-Portuguese.pdf

Brasil. Ministério da Transparência e Fiscalização. (2016c). Relatório de fiscalização n. 201504902. Brasília: Controladoria Geral da União CGU. Retrieved in 2017, June 13, from https://auditoria.cgu.gov.br/download/9609.pdf

Brasil. (2019). Minha Casa, minha vida - Quem pode ter. Caixa Econômica Federal. Retrieved in 2018, December 22, from http://www.caixa.gov.br/voce/habitacao/minha-casa-minha-vida/urbana/Paginas/default.aspx

Campanaro, A., Matera, M., \& Pedroso, F. (2014). Integrated metropolitan planning: a case for DRM in the State of Rio de Janeiro. Retrieved in 2017, January 25, from

http://documents.worldbank.org/curated/en/869031468012645063/pdf/865190BRI0Insi0ue040FINAL00PUBL IC0.pdf

Coelho Netto, A. L. (2011, 3-7 october). The extreme landslide disaster in Brazil. In Proceedings of the Second World Landslide Forum (pp. 1-6). Rome: Food and Agriculture Organization of the United Nations Rome. Retrieved in 2018, January 26, from https://www.researchgate.net/profile/Pedro_Lima9/publication/306503532_January_2011_The_Extreme_Landsl ide_Disaster_in_Brazil/links/57beb2e508aeda1ec3864668/January-2011-The-Extreme-Landslide-Disaster-inBrazil.pdf?origin=publication_detail

Cruz, O. (1998). A Ilha de Santa Catarina e o continente próximo: um estudo de geomorfologia costeira. Florianópolis: Editora da UFSC.

Denaldi, R. (2003). Políticas de urbanização de favelas: evolução e impasses (Tese de Doutorado). São Paulo: Universidade de São Paulo. Retrieved in 2016, April 20, from https://www.pucsp.br/ecopolitica/downloads/tes_2003_Politicas_urbanizacao_impasses.pdf

Fernandes, E. (2007). Implementing the urban reform agenda in Brazil. SAGE Publications - Environment and Urbanization, 19(1), 177-189. http://dx.doi.org/10.1177/0956247807076724.

Florianópolis. Prefeitura Municipal. (1998). Plano diretor do distrito sede do município de Florianópolis. Florianópolis: Instituto de Planejamento Urbano de Florianópolis - IPUF.

Florianópolis. Prefeitura Municipal. (2007). Subprojeto de trabalho técnico social. Projeto Maciço do Morro da Cruz. Florianópolis: Secretaria Municipal de Habitação e Saneamento Ambiental, Programa de Aceleração do Crescimento.

Florianópolis. Prefeitura Municipal. (2008a). Projetos e ações no maciço do Morro da Cruz. Florianópolis: Secretaria Municipal de Habitação e Saneamento Ambiental. Retrieved in 2016, December 15, from http://www.pmf.sc.gov.br/arquivos/arquivos/pdf/07_12_2009_17.54.05.21d784d2f1c7f6374536382850dda3da. pdf 
Florianópolis. Prefeitura Municipal. (2008b). Subprojeto de trabalho técnico social. Projeto Maciço do Morro da Cruz. Florianópolis: Secretaria Municipal de Habitação e Saneamento Ambiental, Programa de Aceleração do Crescimento.

Florianópolis. Prefeitura Municipal. (2011). Plano municipal integrado de saneamento básico. Retrieved in 2016, March 03, from http://portal.pmf.sc.gov.br/arquivos/arquivos/pdf/23_02_2011_14.10.48.ef4fafff9080123c24722cf58ca7eb78.pdf

Florianópolis. Prefeitura Municipal. (2012). Síntese do plano de manejo do parque natural municipal do Morro da Cruz. Florianópolis: PMF.

Florianópolis. Prefeitura Municipal. (2014). Lei Complementar n. 482, de 17 de janeiro de 2014. Institui o plano diretor de urbanismo do município de Florianópolis que dispõe sobre a política de desenvolvimento urbano, o plano de uso e ocupação, os instrumentos urbanísticos e o sistema de gestão. Florianópolis: Diário Oficial Eletrônico do Município. Retrieved in 2016, May 12, from http://www.pmf.sc.gov.br/arquivos/arquivos/pdf/04_02_2014_12.01.39.ae8afdb369c91e13ca6efcc14b25e055.pdf

Gorski, M. C. B. (2010). Rios e cidades: ruptura e reconciliação. São Paulo: Senac.

Instituto Brasileiro de Geografia e Estatística - IBGE. (2011). Census 2010 - Resultado da amostra. Retrieved in 2016, March 20, from http://www.censo2010.ibge.gov.br/apps/mapa/

Kovacic, Z., \& Giampietro, M. (2016). Between theory and quantification: an integrated analysis of metabolic patterns of informal urban settlements. Energy Policy, 100, 377-386.

http://dx.doi.org/10.1016/j.enpol.2016.06.047.

Machado, R. (2011). Morro da Cruz cliff. Retrieved in 2017, July 23, from

http://ruymachado.com.br/index.php?pg=imagens\&src=temas\&tema=57

Maricato, E. (2001). Brasil, cidades: alternativas para a crise urbana. Petrópolis: Vozes.

Moraes, S. T. (2018). Áreas urbanas inundáveis, perspectivas de gestão nos contextos francês e brasileiro. CONFINS, 36. http://dx.doi.org/10.4000/confins.13488.

Moretti, R. S., Comaru, F. E., \& Samora, P. R. (2009). Definição das diretrizes de intervenção - operacionalização das intervenções integradas em assentamentos precários. In R. Denaldi (Org.), Ações integradas de urbanização de assentamentos precários (vol. 1). pp. 203-234.). Brasília: Ministério das Cidades. http://dx.doi.org/10.1590/22369996.2016-3505

Nasa. (2011). Earth observatory - Landslides in Brazil. Retrieved in 2018, January 10, from https://earthobservatory.nasa.gov/images/49120/landslides-in-brazil

Pandini, D. (2017). New houses removal in Alto da Caieira. Retrieved in 2017, June 30, from http://horadesantacatarina.clicrbs.com.br/sc/geral/noticia/2017/06/casebres-sao-derrubados-durantereintegracao-de-posse-da-prefeitura-de-florianopolis-9808557.html

Pasternak, S. (2016). Habitação e saúde. Estudos Avançados, 30(86), 51-66. http://dx.doi.org/10.1590/S010340142016.00100004 .

Qiu, J. (2014). Landslide risks rise up agenda. Forum on deadly natural phenomena discusses use of simulation and hazard-mapping technologies. Nature, 511(7509), 272-273. http://dx.doi.org/10.1038/511272a.

Rego Neto, C. B. (1987). Mapa de uso do solo recomendado (Morro da Cruz - Florianópolis - S.C.) (Dissertação de mestrado). Universidade Federal do Rio de Janeiro - UFRJ, Rio de Janeiro.

Rego Neto, C. B., \& Rosa Filho, O. (1986). Carta geotécnica das encostas do perímetro urbano de Florianópolis Morro da Cruz - Parte 1. Florianópolis: Prefeitura Municipal de Florianópolis, Instituto de Planejamento Urbano de Florianópolis - IPUF, Coordenadoria de Planos e Programas - COPLAN.

Undp-World Bank. (1999). Water and sanitation program - Cities alliance for cities without slums - Action plan for moving slum upgrading to scale. Media Workshop India Pvt Ltd. Retrieved in 2017, August 10, from http://web.mit.edu/urbanupgrading/sponsor/ActionPlan.pdf 
Un-Habitat. (2004). Urban governance index conceptual foundation and field test report. Brighton: University of Sussex.

United Nations. (2008). Linking disaster risk reduction and poverty reduction. UNISDR. Retrieved in 2018, November 15, from https://www.unisdr.org/files/3293_LinkingDisasterRiskReductionPovertyReduction.pdf

United Nations. (2015). Office for disaster risk reduction - Sendai Framework for Disaster Risk Reduction. UNISDR. Retrieved in 2017, August 12, from https://www.unisdr.org/we/coordinate/sendai-framework

Universidade Federal de Santa Catarina - UFSC. (2006). Plano municipal de redução de risco. Florianópolis: Centro Universitário de Estudos e Pesquisas sobre Desastres - CEPED. Retrieved in 2016, May 20, from http://www.ceped.ufsc.br/wp-content/uploads/2015/06/PMRR_Fpolis.pdf

Editor: Rodrigo José Firmino.

Recebido: Out. 19, 2017

Aprovado: Jan. 23, 2019 